\title{
Comments
}

\section{ASPECTS OF PAY TELEVISION: REGULATION, CONSTITUTIONAL LAW, ANTITRUST}

On November 3, 1964, a heated contest for the California entertainment dollar ended in victory for the opponents of "pay TV." California voters that day endorsed an initiative banning subscription television and declaring the industry contrary to public policy. ${ }^{1}$ Passage of the initiative, perlaaps the most significant chapter thus far in the controversy between commercial television and pay television, underscores the necessity for consideration of the political, social and legal questions that underlie the controversy.

The initiative adds sections 43-1 through 43-7 to the California Civil Code. ${ }^{2}$ Section 43-1 contains the short title of the act, "the free television act." Section 43-2 declares subscription television contrary to the public policy of the state of California on the grounds that: (1) the public is presently well-served by free television; (2) the development of "any subscription television business would have an adverse effect upon presently licensed television stations which do not make a charge to viewers;" (3) members of the public would thereby be deprived of their present "freedom of choice with respect to television programs, and of the information, instruction and entertainment now readily and freely available to thein;" and (4) that subscription television "would tend to create a monopoly." Section 43-3 prohibits any person from making any charge as a condition for viewing any program on a "home television set." The prohibition extends to television transmissions by any electronic or mechanical means. Section 43-4 declares void and unenforceable all executory contracts that are contrary to section 43-3. Section 43-5 provides that any person injured by a violation of the free television act may recover treble damages, attorney's fees and costs of suit. Section 43-6 exempts from the operation of the act all community antenna systems and hotel and apartment antenna systems where no charge is made to the viewer based on program content, and all nonprofit educational television systems whether closed or open circuit. Section 43-7 provides that if any part of the act is declared unconstitutional, all other parts are to remain in force.

1 Jordan, Caltrorana Statement of Vote, Generat, Eiection, Nov. 3, 1964, at 25. The proposition was passed by a vote of $4,515,013$ yes to $2,286,775$ no.

2 This Comment cites the free television act as CAr. Crv. Cope \$\$ 43-1 through 43-7, following West's ANN. Car. Crv. Code (1965 Supp.). Other editions of the Californin Codes may not adopt this designation. 
In short, the opponents of "pay TV" succeeded in enacting a total ban on home subscription television. Enactment of the initiative does not, however, foreclose further debate. Soon after the initiative went into effect, the promoters of subscription television attempted to file articles of incorporation for a new "pay TV" venture. The Secretary of State refused to file the articles, relying on the initiative. The promoters sued the Secretary, winning a declaratory judgment in the trial court directing the Secretary to file the articles of the proposed corporation. The trial court held the free television act to be an unconstitutional abridgment of free speech as guaranteed by the first amendment to the United States Constitution and article I, section 9 of the California constitution. ${ }^{3}$

In states other than California, and in Canada, subscription television systems are in operation today. ${ }^{4}$ Their continued existence will depend upon resolution of the policy questions raised by section 43-2 of the California Civil Code, upon constitutional considerations of free speech, equal protection and due process of law, and upon the interaction of federal and state regulation of subscription television programming and transmission.

The policy arguments are simply stated. Opponents of subscription television, as California Civil Code section 43-2 indicates, fear that "pay TV" will destroy "free TV." Supporters of subscription television reply that the distinguishing feature of their enterprise is "box office" prograinming: the presentation of attractions for which the customer would normally pay, such as theater or night club entertainment, opera, concerts, and sports. ${ }^{5}$ Basic to this argument is the assumption that a substantial paying audience would permit presentation of programs not commercially feasible on sponsor-financed television. ${ }^{6}$ Finally, promoters deny that pay television will invade the basic programming staple of commercial television-the weekly series. They assert that a subscriber-financed system could not improve substantially on the appeal of these programs; therefore, the argument runs, subscribers would be unwilling to pay for the

3 Weaver v. Jordan, No. 155760, Sacramento County Super. Ct., May 19, 1965 (Perluss, J.). California constitution, article $1, \S 9$ is a free speech guarantee equivalent to that of the first amendment to the United States Constitution. Katzev v. County of Los Angeles, 52 Cal. 2d 360, 341 P.2d 310 (1959).

4 See The Committee on Broadcasting, Report, Car. No. 1753, at 204, 262-71, 342 (1960); notes 46-49 infra and accompanying text.

5 Address by John H. Pinto, Vice President of RKO General Phonevision Company, to Hollywood Advertising Club, March 16, 1964; see HeAD, BroadCasting IN AMertca 177 (1956).

6 See Prospectus of Subscription Television, Inc., October 30, 1963, pp. 3-5, for acknowledgement of the speculative character of this assumption. But see Pay TV Showdown in the Making, Broadcasting, March 15, 1965, pp. 33-40. 
kind of entertainment offered at no direct viewer cost on commercial channels. $^{7}$

The prospects for federal, state and local regulation of subscription television will be taken up in Part II of this Comment, after a brief survey in Part I of the technology and history of subscription television. Central to the discussion of regulation is the FCC's reluctance to take jurisdiction of coaxial cable subscription television transmissions; this apparent reluctance will, unless state regulatory agencies act, foster creation of a "no man's land" in which subscription television will be free from all regulation. ${ }^{8}$ This, Part II will argue, would be undesirable: Federal regulation is necessary to prevent inconsistent state standards from impeding the orderly development of a medium of communication which is almost certain to move into new geographic areas.

Part III argues that while the free television act, or any similar ban on subscription television, is not subject to challenge under the due process clause, it may violate the fourteenth amendment guarantee of equal protection and the first amendment guarantee of free speech, applied to the states through the fourteenth amendment.

In Part IV, the antitrust problems raised by subscription television will be considered. Subscription television promoters may have occasion to use the antitrust laws to attack unfair methods of competition designed to exclude them from markets already occupied by commercial television and inotion pictures. ${ }^{9}$ They may also have cause to fear attack under the antitrust laws on the basis of long-term contracts concluded with motion picture and sports promoters. ${ }^{10}$

\section{I}

\section{TECHNOLOGX AND HISTORY}

Disagreement over the proper source of broadcasting revenue is not a recent development: Prior to passage of the Communications Act of 1934, many people urged that radio broadcasting be kept free of advertising. ${ }^{11}$ Even the pioneers of television envisioned the creation of subscription television systems. ${ }^{12}$ Subscription television today, however, faces an

7 Address by John H. Pinto, supra note 5.

8 See notes 34-77 infra and accompanying text.

9 See notes 270-304 infra and accompanying text. Subscription Television, Inc. is plaintiff in an antitrust suit against the sponsors of the California initiative. Ibid.

10 See notes 305-35 infra and accompanying text.

11 HEAD, op. cit. supra note 5, at 122-24. For a survey of the economics of radio broadcasting, see id. at 105-24; White, The American Radio 27-67 (1947); cf. HIII, Voluntary IISTENER-SPONSORSHIP passim (1958).

12 See Stepmann, Radro, Tereviston and Socretr 325 (1950); notes 24-27 infra and accompanying text. A survey of the economics of television in its early stages appears in StepMaANN, op. cit. supra at 317-52; see HEAD, op. cit. supra note 5, at 177. 
establishment of commercial sponsorship that has enabled the broadcasting industry to evolve into a large scale network system, ${ }^{13}$ embracing both radio and television communication and providing the public with entertainment and information at relatively low direct cost. Tliat subscription television has lagged behind commercial broadcasting is due in large part to technical and economic considerations.

\section{A. Technical and Economic Survey}

Exploitation of the potential subscription television market requires equipment sufficiently sophisticated both to deliver programs to subscribers and to prevent reception by nonsubscribers. ${ }^{14}$ Two technologically adequate approaches to customer delivery and differentiation have been devised: the radio telegraphy or airwave system, and the closed circuit or wire system. The airwave system transmits television sound and picture conventionally, with the exception that the station scrambles the visual pliase of transmission to prevent reception by nonsubscribers. "Decoders," attachable to any standard television set, unscramble the distorted picture. The wire system delivers both sound and picture through a coaxial cable connected to the subscriber's television set by means of "drop lines."

The two systems differ in a number of important ways. The airwave system is generally restricted to one signal (one program) per channel. The wire system, on the other hand, can deliver three or more programs simultaneously on one cable $;^{15}$ the programs are fed into a program selector attached to the set. Once the viewer has tuned his set to the cliaunel on which the transmitting station operates, he obtains the desired program by tuning the program selector to a subchannel.

Perhaps a more significant characteristic differentiating the two systems is that of cost, both initially and during operation. The airwave system requires a relatively small capital outlay. A conventional television

${ }^{13}$ See, e.g., How They'll Split the $\$ 10$ Million, Broadcasting, May 25, 1964, pp. 27-28.

14 See material cited note 12 supra. Lewis Hill, founder of Pacifica Foundation (which now owns three FM stations), offered the theory that an FM radio station which sought voluntary subscriptions from listeners, giving them in exchange a program guide, could broadcast to subscribers and nonsubscribers alike without attempting to make the privilege of listening exclusive. See Hrrr, op. cit. supra note 11, at 2-4. Whether, in view of the costs attendant upon television broadcasting, a "voluntary" subscription plan would be feasible is open to serious question. KQED, an educational station in San Francisco, is able to supply only a part of its broadcasting budget from voluntary subscriptions of the type Hill envisioned.

15 International Telemeter now operates a wire pay television system with three programs available. See Pay TV to Invade the South, Broadcasting, July 27, 1964, pp. 52-54. Subscription Television (STV)'s system also provided three channels. Broadcasting, June 29, 1964, pp. 58-59. 
station can scramble its signal at slight cost; ${ }^{18}$ the only major expense is the manufacture and installation of the decoders, at a cost of approximately one hundred dollars each. ${ }^{17}$ By contrast, installation of a wire system entails a large initial capital investment. Because the cost of acquiring easements and conduits for laying cable is prolibitive, pay television operations must arrange to use the facilities of local telephone companies, which usually rent or lease transmission cable for radio and TV broadcasting. ${ }^{18}$ As public utilities, teleplione companies generally require large advance deposits to cover cable laying costs should the television venture fail. ${ }^{19}$ Although the deposits are refundable, considerable capital is tied up for an extended period of time. Further, rental rates for the use of telephone company facilities must be approved by the appropriate state utility regulatory body and have been characterized-at least by the pay television industry-as nearly prolibitive in themselves. ${ }^{20}$ Finally, the cost of manufacture and installation of the program selector nust be considered. ${ }^{21}$

In addition to its economic advantages, the airwave system, in most cases, permits immediate access to a substantially larger subscriber area. ${ }^{22}$ Anyone whose set is capable of receiving the station's signal may install the decoder device. The wire system's market, by contrast, is limited to those areas where cable has been laid.

The airwave system lias its disadvantages, however. Experience lias shown that once cable is laid, the percentage of wire hook-ups in the area is greater than the corresponding percentage of airwave decoder attachments. ${ }^{23}$ In addition, simultaneous transmission of several selections affords the wire system intense coverage of a given marketing area; pro-

16 Interview with Steven Hawes, television consultant, University of California, Berkeley, Nov. 6, 1964; see Gelman, Pay TV: So Near and Yet So Far Away, Television, April 1963, p. 104.

17 Interview with Steven Hawes, supra note 16. The decoder must be sophisticated enough to prevent nonsubscribers from easily breaking the "code" and pirating the programs. Some systems circumvent this problem by separating the audio and video signals and transmitting the former over closed circuit cables. See Gelman, supra note 16, at 104.

18 See No Poles for CATV, But Bell Has Service To Sell, Broadcasting, Oct. 19, 1964, pp. 28-30.

$10 \mathrm{Ibid}$. The company may require a long term commitment from a pay TV operator as a condition to granting use of cable facilities. This commitment may be an alternative to a deposit. Id. at 29-30; see Will Vote Halt Pay TV's Growth, Broadcasting, Nov. 9, 1964, pp. 21-22.

20 See Gelman, supra note 16 , at 73.

21 STV paid approximately $\$ 50$ per program selector, excluding cost of installation. See CATV Into Pay TV? Not So Easy, Broadcasting, July 13, 1964, p. 27.

22 See $A$ Gloomy Evaluation of Pay TV, Broadcasting, Aug. 9, 1965, p. 46, at 47; Gelman, supra note 16, at 104.

${ }^{23}$ Ibid. 
grams may be televised a number of times in order to provide maximum exposure of each. The multichannel character of the wire system also permits transmission of continuous recorded music, available at a nominal cost to the subscriber. Further, reception of wire system transmissions is free from interference, an item of particular benefit in color broadcasting.

\section{B. Some Historical Highlights}

In 1941, the Muzak corporation was granted an experimental license for a subscription music service in New York. ${ }^{24}$ In granting the hicense, the FCC stated that subscription broadcasting of the Muzak type offers:

a diversified high quality program service which will be available to the public generally upon subscription and payment therefor. The applicant will broadcast no commercially sponsored programs, and no advertising continuity whatever will be used. Special receiving equipment will be leased by the applicant to those who subscribed for the service. Reception by persons other than subscribers will be prevented by means of a discordant sound ... which can be ehminated only by the use of such special receiving equipment. ${ }^{25}$

Even before the Muzak experience, Zemith laboratories had begun researcl on a subscription television system known as "Phonevision."26 The failure of Zemith's and other early systems can be attributed in part to technical barriers and marketing errors. ${ }^{27}$

The latest and largest operation was Subscription Television (STV) in California. Prior to passage of the California initiative, STV was allegedly losing 10,000 dollars per day, with total losses estimated at more than a million dollars. ${ }^{28}$ Unlike the earlier systems, STV was technically sound and was situated in a population area sufficiently dense to permit expectations of profitable operations. STV's short hife ${ }^{29}$ prior to passage of the mitiative renders estimates as to its potential for successful operations highly speculative.

A recent development which may liave a significant impact on pay television has been the establisliment of commumity antenna television systems (CATV). ${ }^{30}$ CATV brings clear signals to homes in areas which

24 In the matter of Muzak Corp., 8 F.C.C. 581 (1941); see discussion 12 AIR L. REv. 299 (1941).

258 F.C.C. at 581.

26 Zenith's efforts began in 1931; the first public demonstration occurred in 1947. Gelman, supra note 16, at 74-75.

27 Id. at 75. For discussion of other pay TV systems, see A Gloomy Evaluation of Pay TV, Broadcasting, Aug. 9, 1965, p. 46.

28 Will Vote Halt Pay TV's Growth?, Broadcasting, Nov. 9, 1964, p. 21.

29 Id. at 23-24.

30 There were approximately 1600 CATV systems in operation in the suninier of 1965. CATV Growth Paced by Problems, Broadcasting, July 26, 1965, p. 31; see CATV and 
suffer poor reception due to distance from transmitters or to interference caused by irregular terrain. The signals from commercial stations are amplified through the use of microwave relay stations or captured by high master antemias and retransmitted by cable to local subscribers. Approximately two million American homes now receive commercial broadcasts through CATV systems. ${ }^{31}$ Although CATV is in greatest demand in remote scattered communities, significant concentrations have been developing in the highly populated states of Cahifornia and Pennsylvania-and recently in New York City where tall buildings are said to interfere with quality reception. ${ }^{32}$

Because CATV systems involve many features similar to wire pay television, it is possible that CATV facilities can be adapted to provide both services. ${ }^{33}$ If so, the economic factors favoring airwave delivery systems may be offset sufficiently to make wire systems the more feasible alternative.

The technological innovations to be reckoned with may, then, be briefly summarized: the advent of relatively inexpensive decoders for airwave broadcasts and the even less expensive channel selectors for cable broadcasts, the possibility of using telephone company cable for subscription TV broadcasting, and the growth of CATV systems. The concentration of large population groups in great metropolitan areas provides a series of markets for subscription television. The prospect of substantial returns induced many businessmen to invest in subscription television. It is time, therefore, for federal and state governments to consider the proper place of subscription television in communications and public utility regulation.

\section{II}

\section{GOVERNMENTAL REGULATION OF SUBSCRIPTION TELEVISION}

Federal power to regulate broadcasting is derived from the commerce power granted to Congress by the Constitution. ${ }^{34}$ Most broadcasting is interstate by nature: ${ }^{35}$ Technological limitations preclude complete con-

TV Repeater Services, 26 F.C.C. 403 (1959); Notice of Inquiry and Proposed Rulemaking Re All CATV Systems, I F.C.C.2d 453 (1965).

31 CATV Growth Paced by Problems, supra note 30.

32 See Notice of Inquiry and Proposed Rulemaking Re All CATV Systems, 1 F.C.C.2d 453, 455 (1965).

33 For a good survey of the economic problems involved in converting CATV to pay TV, see CATV Into Pay TV? Not So Easy, Broadcasting, July 13, 1964, pp. 27-30.

34 Article I, $\S 8$ of the Constitution provides in part: "The Congress shall have Power ... to regulate Commerce ... among the several States ...."

35 "By its very nature broadcasting transcends state hines and is national in its scope and importance-characteristics which bring it within the purpose and protection, and subject it to the control, of the commerce clause." Fisher's Blend Station, Inc. v. State 
trol .over the ultimate destination of airwave transmissions and some signals invariably cross state lines. ${ }^{36}$ In addition to inadvertent interstate transmission, programs frequently travel between states, either in the form of videotape or as transmissions via cable or microwave relay stations. ${ }^{37}$ Even the station that broadcasts only locally "affects" interstate commerce. ${ }^{38}$

Closed circuit delivery systems, however, permit broadcasters to avoid inadvertent interstate transmission. In addition, the shielding characteristic of the closed circuit method virtually eliminates the threat of interference with other transmissions. ${ }^{39}$ Nevertheless, closed circuit pay television will compete with commercial television for the attention of television audiences. Many programs broadcast over closed circuit facilities will undoubtedly originate out-of-state. The existence of large closed circuit pay television systems undoubtedly would have a "substantial economic effect" on commercial television-thus justifying the assertion of federal authority over all pay television operations. ${ }^{40}$

Tax Comm'n, 297 U.S. 650, 655 (1936). "No state lines divide the radio waves, and national regulation is not only appropriate but essential to the efficient use of radio facilities." Federal Radio Comm'n v. Nelson Bros. Bond \& Mortgage Co., 289 U.S. 266, 279 (1933); Allen B. Dumont Labs. v. Carroll, 184 F.2d 153, 154-55 (3d Cir. 1950), cert. denied, 340 U.S. 929 (1951).

36 Allen B. Dumont Labs. v. Carroll, supra note 35, at 154.

37 In its suit for a writ of mandate directing the California Secretary of State not to file election results on the ban, STV asserted that its plans included the transmission to California viewers of "a substantial number of programs and attractions made and originated in states other than California . . . " as well as all out-of-state games played by the San Francisco Giants and the Los Angeles Dodgers. Brief for Petitioner, pp. 3-4, 11-14, Kevelin v. Jordan, 62 Cal. 2d 82, 396 P.2d 585, 41 Cal. Rptr. 169 (1964).

38 The Communications Act grants to the FCC licensing power over the transmission of energy by radio in interstate and foreign commerce and where the transmission of communications is "within any state when the effects of such use extend beyond the borders of said State, or when interference is caused by such use or operation with the transmission of such energy . . . fronl within said State to any place beyond its borders, or from any place beyond its borders to any place within said State . . . 48 Stat. 1081 (1934), 47 U.S.C. 301 (1964). See United States v. Gregg, 5 F. Supp. 848 (S.D. Tex. 1934): The Radio Act of 1927 [predecessor to the Conimunications Act of 1934] prohibited broadcasting by an unlicensed broadcaster where transmission interfered with signals in another state.

39 Press release from Lear Siegler, Inc., suppliers of electronic equipment to STV, undated (1964); Interview with Steven Hawes, supra note 16. The problems of inadvertent transmission are similar to those created by wire CATV systems. See CATV and TV Repeater Services, 26 F.C.C. 403, 425 (1959).

40 Even if activity "be local and though it may not be regarded as commerce, it may still, whatever its nature, be reached by Congress if it exerts a substantial economic effect on interstate conunierce, and this irrespective of whether such effect is what might at some earlier time have been defined as 'direct' or 'indirect.' Wickard v. Filburn, 317 U.S. 111, 125 (1942). The "substantial economic effect" basis for the reach of congressional power reaches far. In Wickard, the Supreme Court upheld federal power over a small farmer's crop of several hundred bushels of wheat, produced in part for use on the grower's farm 
The allocation of regulatory authority over pay television has never been clearly defined. While federal regulatory power has some pre-emptive effect, ${ }^{41}$ regulation may be attempted by local communities, by state public utility commissions, by state legislation, or by any combination of these. The broadcaster's difficulty in choosing between alternative delivery systems is thus compounded by the risk of inconsistent decisions by regulatory bodies and his uncertainty as to the validity of state or local regulation. The need for clarification is apparent.

\section{A. Federal Regulation}

Federal regulatory power over broadcasting is articulated in the Federal Communications Act. ${ }^{42}$ The Act establislied the Federal Communications Commission (FCC), ${ }^{43}$ and granted the Commission the authority to allocate the limited number of available broadcasting frequencies and to regulate broadcasting generally. ${ }^{44}$ The FCC is governed in fulfilling these duties by the standard of the "public convenience, interest, or necessity."

In 1959 the FCC agreed to accept applications for temporary pay television licenses for specified test markets. ${ }^{46}$ Experience in these markets was to provide the FCC with information regarding the probable impact of pay television on commercial television. ${ }^{47} \mathrm{~A}$ few experimental licenses

and for his own personal consumption. Supplying additional guidelines for determining the reach of federal power, the Court has commented that the commerce power "extends to those activities intrastate which so affect interstate counmerce, or the exertion of the power of Congress over it, as to make regulation of then appropriate means to the attainment of a legitimate end .... [T] activities which in a substantial way interfere with or ohstruct the exercise of the granted power." United States v. Wrightwood Dairy Co., 315 U.S. 110, 119 (1942). Both of these statements were recently repeated by the Supreme Court in testing the exercise of the commerce power in the 1964 Civil Rights Act. Katzenbach v. McClung, 379 U.S. 294 (1964).

41 See notes 78-118 infra and accompanying text.

42 Also known as the Communications Act of 1934, 48 Stat. 1064, as amended, 47 U.S.C. $\$ \S 151-609$ (1964). The present statute was preceded by the Radio Act of 1927, 44 Stat. 1436 (1927).

43 Formerly, the Federal Radio Commission.

44 See, e.g., 48 Stat. 1083-84 (1934), as amended, 47 U.S.C. $\$ 307$ (1964) (granting and renewing licenses); 48 Stat. 1082 (1934), as amended, 47 U.S.C. \& $303(\mathrm{~m}$ ) (1964) (power to suspend licenses); 48 Stat. 1086-87 (1934), as amended, 47 U.S.C. \& 312(a) (1964) (power to revoke bicenses). See also Federal Communications Conım'n v. American Broadcasting Co., 347 U.S. 284, 289-90 (1954).

4548 Stat. 1083 (1934), as amended, 47 U.S.C. \& 307(a) (1964).

4626 F.C.C. 265 (1959).

47 Among the conditions imposed on pay television license applicants were the provisions that experimental hicenses would be granted only for three-year periods, only one permit would be granted per market, and licenses would be himited to those cities wbich had at least four commercial stations. Id. at 266, 268, 270. "Among the main conditions under which trial operations may be authorized are: (a) a 3-year testing period; (b) operation only in cities within the grade A contours of at least four commercial TV 
have been granted since 1959.48 A federal district court held one such license to be within the Agency's power, stating that a pay television $\mathrm{h}$ cense was not clearly outside the public interest..$^{99}$

Tlie FCC has, however, hmited its supervision of pay television to airwave transmission systems; it has not yet attempted to assume jurisdiction over closed circuit systems. ${ }^{50}$ This restraint stems from a fundamental omission in the coverage of the Act. The Act delegates to the FCC authority over commumication by both wire and "radio"-a general term o that comprehends all electronic communication through radiotelegraphy, including standard airwave television broadcasting ${ }^{51}$-but limits the Commission's jurisdiction in the field of wire communications to authority over "common carriers." 152 Wire dehivery systems are not specifically included in the portion of the Act giving the FCC power over broadcasting; that portion of the Act refers only to transmission by radio..$^{53}$

stations; (c) trial of any system in only one market; (e) both VHF and UHF stations are eligible; (f) a station offering pay-TV must broadcast at least the minimum of free programs required for commercial TV stations; (g) charges, terms and conditions of services must be applied uniformly to subscribers; and $(h)$ the licensee may not sell any special receiving equipment to the public." Federar Comaronications CoMan'N, 28TH ANNUAL REPORT 64-65 (1962).

48 The first hicense was granted to WHCT on Channel 18 at Hartford, Conn. WHCT started programming on Jnne 29,1962 , and is still operating. A second license was granted to station KTVR, on Cliannel 2 in Denver, Colo. on October 3, 1962. A third applicant, station KVUE, Channel 40 in Sacramento, Calif., was returned as unacceptable for failure to comply with the conditions for trial operations. Id. at 69; See Gelman, supra note 16, at 104 .

40 Connecticut Comm. Against Pay TV v. FCC, 301 F.2d 835 (D.C. Cir. 1962).

50 But see notes 54-65 infra and accompanying text.

51 Holding that television is included in the term "radio" or "radiotelegraply": Allen B. Dumont Labs v. Carroll, 184 F.2d 153 (3d Cir. 1950), cert. denied, 340 U.S. 929 (1951); Standard Radio \& Television Co. v. Chronicle Publ. Co., 182 Cal. App. 2d 293, 6 Cal. Rptr. 246 (1960).

5248 Stat. 1066, 1070-81 (1934), 57 Stat. 5 (1943), as amended, 47 U.S.C. $\S \S 153(\mathrm{~h})$, 201-22 (1964).

53 "No person shall use or operate any apparatus for the transmission of energy or conımunications or signals by radio (a) from one place in any Territory or possession of the United States or in the District of Columbia to another place in the same Territory, possession, or District; or (b) from any State, Territory, or possession of the United States, or from the District of Columbia to any other State, Territory, or possession of the United States; or (c) from any place in any State, Territory, or possession of the United States, or in the District of Columbia, to any place in any foreign country or to any vessel; or (d) within any State when the effects of such use extend beyond the borders of said State, or when interference is caused by such use or operation with the transmission of such energy, communications, or signals from within said State to any place beyond its borders, or fron any place beyond its borders to any place within said State, or with the transmission or reception of such energy, communications, or signals from and/or to places beyond the borders of said State; or (e) upon any vessel or aircraft of the United States; or (f) upon any other mobile stations within the jurisdiction of the United States, except 
The FCC has never ruled on its authority over closed circuit pay television. It has, however, handed down a series of rulings in the analogous field of CATV transmissions delivered by wire. After an initial refusal to take jurisdiction over wire CATV systems, ${ }^{54}$ the FCC ruled in April 1965 that it would take jurisdiction over all CATV systems in the interest of the orderly development of broadcasting. ${ }^{55}$

The FCC's 1959 refusal to assert jurisdiction relied on three arguments: (1) The Commission reaffirmed that the "common carrier" section of the Communications Act apphes only to systems that provide the vehicles for the transmission of signals by others, not to systems that transmit signals of their own choosing. ${ }^{56}$ (2) To the view that the broadcasting section of the Act covers CATV transmission, the Commission responded that its grant of authority was less than comprehensive: "This section (granting jurisdiction over broadcasting) does not include the transmission of programs by CATV systems, since such transmission is by wire." (3) Replying to the argnment that it had "plenary power" over the communications industry, the FCC stated that whatever power it had did not extend to CATV: "[W]e do not beheve that we have 'plenary power' to regulate any and all enterprises which happen to be connected with one of the many aspects of communications."

The April 1965 reversal of its earlier position was tentative and partial. The Commission "initially concluded" that it has jurisdiction over some aspects of CATV systems that use cables for transmission of signals. ${ }^{59}$ Rules are to be proposed and discussed, and the extent to which the FCC will regulate is at this writing undecided. ${ }^{60}$ The Commission's "Memorandum on Its Jurisdiction and Authority" outlined the reasons for the change. First, CATV systems pose a threat to stations licensed in areas outside the range of big-city stations whose signals are carried on CATV systems. This competition to the stations in remote areas creates the danger of infringement of FCC rules for the effective distribution of broadcast service. The Commission is empowered to deal with such infringement by "any person."

under and in accordance with this chapter and with a license in that bchalf granted under the provisions of this chapter. 48 Stat. 1081 (1934), 47 U.S.C. \& 301 (1964).

5426 F.C.C. 403 (1959); Frontier Broadcasting Co. v. Collier, 24 F.C.C. 251 (1958). 551 F.C.C. $2 \mathrm{~d} 453$ (1965).

5026 F.C.C. $403,427-28$ (1959).

57 Id. at 427 . (Emphasis added.)

58 Id. at 429.

591 F.C.C.2d at 465.

60 Id. at $463-82$.

61 Id. at 479-80. At least this is so when the "person" is engaged in interstate transmission by wire. Ibid. 
section 307(b) of the Communications Act ${ }^{62}$ with effective allocation of broadcasting services. It has, in this connection, "expansive powers" and "comprehensive mandate," according to the Supreme Court in National Broadcasting Co. v. United States. ${ }^{63}$ Citing cases in which the ICC and other agencies have assunied jurisdiction over matters collateral to their central concerns in order to effectively achieve their statutory goals, ${ }^{64}$ the FCC decided that section 307(b) authorizes it to assert jurisdiction over CATV wire systems. ${ }^{65}$

The Commission will, therefore, act to protect presently bicensed broadcasters and to enforce the policies whicli it has shaped under the Communications Act. Barring judicial interdiction, the FCC will apparently take the view that its power is "plenary," at least to the extent necessary to carry out the functions specifically delegated to it in the Communications Act.

There is, however, no FCC statenient at this writing about wire subscription television. Under current FCC decisions, only airwave subscription television systems have been subjected to uniform federal supervisory control. It is possible, however, that as more subscription television systems come to compete with commercial television, the FCC will reevaluate its authority under the Act. While closed circuit delivery systems were not conteniplated at the time the Communications Act was passed, ${ }^{66}$ the language of the Act indicates that authority over them would have been granted to the FCC had closed circuit broadcasting then existed. ${ }^{67}$

The FCC, in addition to the reasons it gave for asserting jurisdiction over all CATV, might consider the arguments whicli follow as a basis for comprehensive regulation of all subscription television. The closed circuit system raises problems analogous to the allocation of facihties problem the Communications Act was desigued to resolve. With conventional television the need for governnient supervision was prompted by the possibility of interference among signals unless the number of frequencies used for transmission was limited ${ }^{68}$ In the case of wire systems, the large capital investment necessary to establisli the system ${ }^{69}$ creates

6248 Stat. 1084 (1934), as amended, 47 U.S.C. $\$ 307$ (b) (1964).

63319 U.S. 190, 215-19 (1943), cited at 1 F.C.C.2d at 480-81.

64 E.g., American Trucking Ass'ns v. United States, 344 U.S. 298 (1953).

65 The Commission also relied upon other sections of the Act, notably $\$ \S 1,4(\mathbf{i})$, 303 (f),(h),(r). I F.C.C.2d at 479-81. However, it adverted particularly to the need that it exercise authority to protect its basic function under $\$ 307(\mathrm{~b})$. Id. at 480 .

66 See generally HEAD, Broadcasting IN America 125-34 (1956).

67 See the language of 47 U.S.C. $\$ 301$ (1964), at notes 38, 53 supra; 48 Stat. 1064 (1934), as amended, 47 U.S.C. \$\$ 151-52 (1964).

${ }^{68}$ National Broadcasting Co. v. United States, 319 U.S. 190, 226 (1943); Federal Radio Comm'n v. Nelson Bros. Bond \& Mortgage Co., 289 U.S. 266, 279 (1933).

69 See text accompanying notes 18-19 supra. 
the allocation problem; in an area where "bread-and-butter" programs such as major sports events and first-run motion pictures are already available to potential subscribers because of a pre-existing system, a new system will lack sales appeal and consequently will have little economic incentive to enter the market. ${ }^{70}$ It seems unhkely that a given geographic area would be able to sustain more than one or two pay television systems. ${ }^{71}$ It appears, therefore, that wire system broadcasting opportunities are limited much as are airwave broadcast opportunities. The goal of providing the public with optimum service would seem to require comparable regulation.

In National Broadcasting Co. v. United States, ${ }^{72}$ however, the Supreme Court adverted to first amendment limits on Congress' power to regulate communications media. The Court said that the physical limitations upon the number of available broadcast frequencies justified the Congress inl setting up an agency to determine who shall broadcast. ${ }^{73}$ Presumably, the Congress could not set up an agency to decide what newspaper should be permitted to serve a given area ${ }^{74}$ competition between papers nuust settle that question. The Court also made clear that the FCC nust use politically neutral criteria in allocating broadcast chaunels, or run the risk of violating the first aniendment. ${ }^{75}$ There are, in FCC constructions of the Communications Act, examples of Commission concern with its power to say who shall broadcast: These include the "equal-tine" requirement, the "fairness" doctrine which requires

70 The STV operation in California, for example, had obtained long-term exclusive contracts with two of the three major league baseball teams in the state. See note 37 supra; notes 306-21 infra and accompanying text. Anyone contemplating establishing a pay television system in California would have been faced with a competition firmly established and offering nearly the same basic programming. While new services could probably be provided, the high financial returns available from baseball and noving pictures would either be foreclosed for many years, or the lucrative attractions already offered to viewers. These conditions substantially reduce the possibility that new competitors will arise to face the first or second pay television broadcaster in any area.

71 In a report to the California legislature, the Assembly Interim Committce on Public Utilities and Corporations found that: "It appears highly improbable more than one closed circuit system can economically be installed in an area. The cost of an additional system would be prohibitive to the customer, which in turn would make him a captive to the first system for which he subscribed." 16 Assemsty InTERTM COMM. REp. No. 7, at 12 (1961).

72 National Broadcasting Co. v. United States, 319 U.S. 190 (1943).

73 Id. at 226: "Freedom of utterance is abridged to many who wish to use the limited facilities of radio. Unlike other modes of expression, radio inherently is not available to all. That is its umique characteristic, and that is why, unlike other modes of expression, it is subject to governmental regulation. Because it cannot be used by all, some who wish to use it must be denied."

74 Ibid.; Near v. Minnesota, 283 U.S. 697 (1931).

75319 U.S. at $226-27$. 
stations to give time to diverse points of view, and the requirement that stations broadcast public service messages and programs.

Viewed agamst these limits on, and purposes of, federal communications regulation, is it reasonable that the FCC take jurisdiction of closed circuit subscription television? The answer seems to be a qualified yes. Subscription television will, as pointed out above, be the province of but one or two concerns in each market area. Practically speaking, the public will liave the same limited choice of programs that it now has in the field of commercial television. Further, the subscription television broadcaster will be in competition with the commercial television broadcaster; consequently, if the subscription television broadcaster is not placed under obligations of equal time, fairness and public service-all of whicl entail sonie expense for the commercial television broadcaster ${ }^{76}$ - he will acquire a competitive advantage.

Both commercial television and subscription television are mass media in or affecting interstate commerce which transmit picture and sound into the liomes of viewers who choose to watch the fare offered. It seems unreasonable to distinguish between then for purposes of regulation. Perhaps because the plysical compulsion to regulate-inherent in the himited number of broadcast channels for commercial and airwave subscription television-is not present in the case of cable subscription television, the first amendment will impose more stringent program content regulation standards upon the FCC. The first amendment does not, however, preclude some regulation of cable subscription television given the FCC's acknowledged plenary power over airwave video transmissions.

Other public interest considerations argue for FCC regulation of wire pay television. Pay television may well harm "free" television. ${ }^{77}$ The FCC should not be forced to wait until actual harm is felt before it steps in to preserve a medium it was created to protect. The grant of authority to supervise electromic communication media would seem to include implied authority to continue to supervise those media though express delegation of authority over unforeseen technological innovations was omitted.

\section{B. The Pre-emption Problem}

The current uncertainty over FCC pohicy on wire subscription television raises questions concerming the degree to which state regulatory power over pay TV may be pre-empted. State legislation is invahd under

70 See Simead, Freedom of Speece by Radio and Televiston 63-73 (1959); Rosenbloom, Authority of the Federal Communications Commission, in Coons, FREEDOM \& RESPONSIBITTY IN BROAdCASTING 96 (1961); Note, Regulation of Program Content by the FCC, 77 Harv. L. Rev. 701, 713-14 (1964).

77 See notes 1-7, 15, 20 supra and accompanying text. 
the supremacy clause ${ }^{78}$ of the Constitution when Congress has acted in an area of supreme federal power and interest, ${ }^{79}$ where state regulation will interfere with or obstruct congressional purposes, ${ }^{80}$ or where federal legislation can be said to have occupied the field. ${ }^{81}$ Although the basis for a finding that state legislation has been pre-empted by the federal government is frequently said to be "intent," there is no talismanic phrase that explains all the pre-emption cases. ${ }^{82}$ The theories supporting a finding of pre-emption vary depending upon the relative urgency of state and federal interests in the particular federal regulatory scheme. ${ }^{83}$

Early judicial pronouncements concerning the scope and preclusive effect of the Communications Act have been repudiated. ${ }^{84}$ The oft-cited statement in Allen B. Dumont Laboratories v. Carroll, ${ }^{85}$ that the intent of Congress in enacting the Communications Act was to "conipletely occupy

78 Article VI of the U.S. Constitution provides in part: "This Constitution, and the Laws of the United States which shall be made in Pursuance thereof; . . . shall be the supreme Law of the Land ....."

79 E.g., Pennsylvania v. Nelson, 350 U.S. 497 (1956); Rice v. Santa Fe Elevator Corp., 331 U.S. 218 (1947); Hines v. Davidowitz, 312 U.S. 52 (1941).

80 E.g., City of Chicago v. Atchison, T. \& S.F. Ry., 357 U.S. 77 (1958); Castle v. Hayes Freight Lines, Inc., 348 U.S. 61 (1954).

81 E.g., San Diego Bldg. Trades Council v. Garmon, 359 U.S. 236 (1959); Garner v. Teamsters Union Local 776, 346 U.S. 485 (1953); Cloverlenf Butter Co. v. Patterson, 315 U.S. 148 (1942).

82 "This Court, in considering the validity of state laws in the light of treaties or federal laws touching the same subject, has made use of the following expressions: conflicting; contrary to; occupying the field; repugnance; difference; irreconcilability; inconsistency; violation; curtailment; and interference. But none of these expressions provides an infallible constitutional test or an exclusive constitutional yardstick. . . . Our primary function is to determine whether, under the circumstances of this particular case, [the State's] . . . law stands as an obstacle to the acconiplishment and execution of the full purpose and objectives of Congress." Hines v. Davidowitz, 312 U.S. 52, 67 (1941).

83 See generally Hunt, State Control of Sedition: The Smith Act as the Suprente Law of the Land, 41 MnNv. L. Rev. 287, 293-99 (1957); Comment, Pre-emption as a Preferential Ground: A New Canon of Construction, 12 Stav. L. REv. 208 (1959). With reference to the broadcasting field and related problems, see Comment, Can CATV Be Enjoined, 20 AlbaNy L. Rev. 69 (1956); Comment, State Regulation of Radio and Television, 73 Harv. L. REv. 386 (1959).

84 The Supreme Court recently stated that when dealing with questions relating to the pre-emptive effect of the Communications Act, "we nay begin by noting that the validity of this claim cannot be judged by reference to broad statements about the 'conzprehensive' nature of federal regulations under the Federal Communications Act." Head v. New Mexico Bd. of Examiners, 374 U.S. 424, 429-30 (1963). The Court was referring to two statements in National Broadcasting Co. v. United States, 319 U.S. 190 (1943) ("wide hicensing and regulatory powers," and "comprehensive powers to promote and realize the vast potentialities of radio," id. at 213, 217) and one in FCC v. Pottsville Broadcasting Co., 309 U.S. 134 (1940) ("unified and comprehensive regulatory systein for the industry," id. at 137). See generally ONeil, Television, Tort Law, \& Federalism, 53 CAI.IF. L. REv. 421, 456-79 (1965).

85184 F.2d 153 (3d Cir. 1950). 
the television broadcasting field in its entirety," courts. ${ }^{87}$ More recently, in Head v. New Mexico Board, ${ }^{88}$ the Supreme Court set forth the standards governing pre-emption in the field of broadcasting. Stating that the field does not require national uniformity, the Court concluded: "[S] tate statutes, otherwise vahi, must be upheld unless there is found 'such actual conflict between the two schemes of regulation that both cannot stand in the same area, or evidence of a congressional desigu to preempt the field.' " 889

That the federal government has occupied the field of airwave broadcasting through FCC hicensing is not open to doubt. ${ }^{90}$ State attempts to regulate federally hicensed operations have long been recoguized as invalid interference with congressional desigu. ${ }^{91}$ The FCC's April 1965 assumption of jurisdiction over wire CATV systems leaves in doubt the extent to which state regulation of wire subscription television may be or has been pre-empted. The FCC's own statement on pre-emption in the CATV field, provides some guide:

[I]n the event it is ultimately determined that the Commission has jurisdiction over all CATV systems, we do not contemplate regulation of such matters as CATV rates to subscribers, the extent of service to be provided, or the award of CATV franchises. Apart from the areas in which the Commission has specifically indicated concern and until such time as regulatory measures are proposed, no Federal preemption is intended. ${ }^{92}$

For the present, then, the Commission intends to proceed cautiously on matters, such as wire CATV service, that are at the outer limits of its jurisdiction under the Communications Act. ${ }^{93}$ Since wire CATV raises jurisdictional problems analogous to those raised by wire subscription television, caution in the latter field may be expected as well. Use of intrastate public utility facilities such as telephone cables and electric power, matters in which state authority to regulate is recoguized ${ }^{94}$ will probably continue to be governed by state law. State decisions in the field

86 Id. at 155. "We think it is clear that Congress has occupied fully the field of television regulation and that field is no longer open to the states." Id. at 156.

87 E.g., Standard Radio \& Television Co. v. Chronicle Publ. Co., 182 Cal. App. 2d 293, 6 Cal. Rptr. 246 (1960).

88374 U.S. 424 (1963).

$89 \mathrm{Id}$. at 430 .

${ }^{90}$ See Connecticut Comm. Against Pay TV v. FCC, 301 F.2d 835 (D.C. Cir. 1962); 26 F.C.C. 265 (1959), and the discussion accompanying notes $34-49,83$ supra.

91 See, e.g., City of Chicago v. Atchison, T. \& S.F. Ry. Co., 357 U.S. 77 (1958); Castle v. Hayes Freight Lines, 348 U.S. 61 (1954).

921 F.C.C.2d at 466 (Emphasis added.); cf. text accompanying notes 34-49 supra.

931 F.C.C.2d at $463-77$, and note the cautious and tentative tenor of the Commission's discussion.

94 See notes 95-118 infra and accompanying text; 1 F.C.C.2d at 466. 
of subscription television and CATV have, however, been inconsistent.

The Arkansas Supreme Court, asked to decide whether state regulation of wire pay television had been pre-empted, bypassed the question. The case concerned the jurisdiction of the Arkansas Public Service Commission over a petition by a closed circuit pay television system to use telephone company facilities solely within the state. ${ }^{95}$ The court upheld the power of the Commission to permit the use of telephone facilities on the ground that the Communications Act reserved to the states jurisdiction over carriers' intrastate wire transmissions. ${ }^{96}$ Although the decision was correct as to state jurisdiction over common carriers and carrier facilities, television broadcasters are not carriers; ${ }^{97}$ the decision's effect on the television company was incidental to the confirmation of the commission's jurisdiction over telephone facilities.

A number of other state public utility regulatory bodies have faced the pre-emption problem in connection with tests of their jurisdiction, and with varying results. For example, the Wisconsin Public Service Commission rejected jurisdiction over wire television on the ground that the Federal Communications Act fully occupies the field of television regulation; ;8 $^{88}$ the Wyoming Public Service Commission, on the other hand, found that it had jurisdiction over CATV systems using wire transmission from a master antemia to subscribers' homes. ${ }^{90}$

The Wyoming Commission's assertion of jurisdiction was based on the premise that rebroadcasts of television signals by wire takes these signals completely out of the stream of interstate commerce. ${ }^{100}$ Therefore, the argument goes, CATV operators are not engaged in "broadcasting" within the meaning of the Federal Communications Act. This premise is open to question since wire television systems operating on facilities exclusively within the boundaries of a single state invariably have suffcient interstate contacts to permit congressional regulation under the commerce power. ${ }^{101}$ The Commission noted ${ }^{102}$ that the FCC had as of the

95 Independent Theatre Owners v. Arkansas Publ. Serv. Comm'n, 235 Ark. 668, 361 S.W.2d 642 (1962).

${ }^{96} \S 152$ of the Communications Act provides in part: "[N]othing in this chapter shall be construed to apply or to give the Commission jurisdiction with respect to (1) charges, classifications, practices, services, facilities, or regulations for or in connection with intrastate commumication service by wire or radio of any carrier ..." 48 Stat. 1065, as amended, 47 U.S.C. $\$ 152$ (b) (1964). (Emphasis added.)

97 See text accompanying note 56 supra.

$98 R e$ Bennett, 89 P.U.R. (N.S.) 149 (Wis. Publ. Serv. Comm'n 1951). 1958).

99 Re Community Tclevision Systems, 23 P.U.R.3d 444 (Wyo. Publ. Serv. Comm'n

$100 I d$. at 449.

101 See note 40 supra and accompanying text.

10223 P.U.R.3d at 449. 
time of its decision refused to take jurisdiction over CATV; ${ }^{103}$ yet the FCC, in that refusal, did not mention interstate contacts, but took the position that, even if CATV systems were held to be a form of broadcasting, that would not in itself be sufficient to give the FCC jurisdiction. ${ }^{104}$

Nevertheless, the Wyoming Commission made a persuasive argument for state jurisdiction by stressing the need to avoid a regulatory vacuum in the absence of FCC jurisdiction. "Community antenna television service is a form of pay television. If persons furnishing this type of service are not controlled and regulated by a government agency, the door is left open to them to charge exorbitant rates, to arbitrarily refuse service, and to discriminate between subscribers." ${ }^{105}$ Because of television's potent social impact, the creation of a "no-man's land" by finding that state regulation is pre-empted seems particularly undesirable. This is especially so given the subsequent FCC statement that it will not seek to regulate CATV rates and similar matters. ${ }^{106}$

The Wyommg Commission's decision also seems proper under the guidelines set forth by the Supreme Court in Head. ${ }^{107}$ First, Head affirmed that radio and television broadcasting is not a field "inherently requiring national uniformity."108 Second, that closed circuit television was unknown to Congress when the Federal Communications Act was passed makes doubtful any "congressional desigu to pre-empt the field." Although it has been suggested that the FCC should attempt to occupy the fields of subscription television and CATV, ${ }^{110}$ the FCC has thus far refused to do so. In light of that refusal it seems unwise to attribute to Congress a desigu to supersede state legislation in the field. ${ }^{111}$ That the

${ }^{103}$ CATV and TV Repeater Services, 26 F.C.C. 403, 428-29 (1959). See also Frontier Broadcasting Co. v. Collier, 24 F.C.C. 251 (1958). But see notes 55-67 supra and accompanying text.

104 CATV and TV Repeater Services, supra note 103, at 429. But see notes 55-67 supra and accompanying text.

${ }_{105} \operatorname{Re}$ Commumity Television Systems, 23 P.U.R.3d 444, 448 (Wyo. Publ. Serv. Comm'n 1958).

106 Notice of Inquiry and Proposed Rulemaking $R e$ All CATV Systems, 1 F.C.C.2d 453, 466 (1965).

107 Head v. New Mexico Bd. of Examiners, 374 U.S. 424 (1963). Compare Southern Pac. Co. v. Arizona, 325 U.S. 761 (1945); Hines v. Davidowitz, 312 U.S. 52 (1941).

108374 U.S. at 430.

109 Id. at 430 , quoting Florida Lime \& Avocado Growers v. Paul, 373 U.S. 132, 141 (1963).

110 See Notice of Inquiry and Proposed Rulemaking Re All CATV Systems, I F.C.C.2d $453,453-63$; notes 54-65 supra and accompanying text.

111 Justice Brennan, concurring in the Head decision, asserted that rather than evidence of congressional intent to occupy the field, the Communications Act suggested a "congressional design to leave standing various forms of state regulation ...." Justice Brennan pointed to $\$ 414$ of the Act "saving" remedies existing at common law or by statute at the 
FCC might be able to assert jurisdiction over both wire subscription television and CATV is not in itself sufficient to imply congressional intention to pre-empt the field; the implied statutory authority for an FCC assertion of jurisdiction could liave been intended as nonexclusive. The third test-whether as a practical matter, both state and federal regulations can be enforced without impairing federal superintendence of the field ${ }^{112}$-also leads to a conclusion of no pre-emption, so long as the FCC declines to supervise all aspects of closed circuit systems.

Notwithstanding these indications that state regulation of wire television is not pre-empted, there is at least one counter-argument. The Supreme Court has applied different standards for pre-emption in other fields of federal regulation. ${ }^{113}$ In labor relations, for example, the National Labor Relations Board (NLRB) has exclusive authority over activities which are "arguably subject" to the National Labor Relations Act, whether or not the NLRB lias declined to take jurisdiction of a dispute. ${ }^{114}$ Because a reasonable argument may be made that wire systems are completely within FCC jurisdiction, ${ }^{115}$ application of an "arguably subject" standard miglit compel a finding of exclusive federal control over closed circuit television. Both the National Labor Relations Act and the Federal Communications Act involve subjects of national importance and, thus, strong federal concern. Still, the "arguably subject" standard may be limited to instances of "primary jurisdiction" as in the labor cases. ${ }^{110}$ In view of the trend of recent broadcasting cases away from pre-emption absent actual conflict between state and federal regulation, it appears unlikely that the courts will apply the "arguably subject" standard to broadcasting. The "no man's land" problen engendered by use of the "arguably subject" standard in the labor field adds substance to this conclusion. ${ }^{117}$

The desirability of exclusive federal jurisdiction seems clear, low-

time of the Act as "inconsistent with congressional displacement of the state statute unless a finding of that meaning is unavoidable." He also stated that a similar inference could be drawn from the fact that the statutory regulation of radio and television was less comprehensive than the regulation in the same title of telephone and telegraph facilities. 374 U.S. at $443-44$.

112374 U.S. at 444 (concurring opinion of Brennan, J.).

113 See generally Hunt, supra note 83, at 293-99.

114 San Diego Bldg. Trades Council v. Garmon, 359 U.S. 236, 245 (1959); Amalgamated Meat Cutters v. Fairlawn Meats, Inc., 353 U.S. 20 (1957); Guss v. Utah Labor Relations Bd., 353 U.S. 1 (1957).

115 See notes 54-65 supra and accompanying text; Notice of Inquiry and Proposed Rulemaking $R e$ All CATV Systems, 1 F.C.C.2d 453 (1965).

116 See San Diego Bldg. Trades Council v. Garmon, 359 U.S. 236, 244-45 (1959).

117 Some of these problems are adverted to in Guss v. Utah Labor Bd., 353 U.S. 1, 12 (1957) (dissenting opinion). See Head v. New Mexico Bd. of Examiners, 374 U.S. 424, 446-47 (1963) (concurring opinion of Brennan, J.). 
ever: It would provide uniformity of treatment of closed circuit systems among the states, permit parallel regulation for airwave and closed circuit pay television, insure continuity of regulation over all broadcasting, and protect the public from wliatever threats to free television are offered by pay television. The FCC will be hesitant to act boldly, however, given the present limits on its authority, and the courts are understandably reluctant to rewrite the Communications Act. Until the gap is filled by federal legislation putting all broadcasting under the jurisdiction of the FCC, and notwithstanding that a finding of pre-emption miglit encourage Congress to step into the "no-man's land" thereby created, the unpredictability of congressional response suggests that the better alternative is to uphold state legislation against a challenge of pre-emption absent actual conflict with FCC rulings. A finding of limited or no pre-emption ${ }^{118}$ would at least leave closed circuit pay television subject to state regulation. If state regulation proves inadequate, or leads to creation of inconsistent standards, these sliortcomings may be put forward as an argument for FCC or congressional intervention.

\section{Public Utility. Regulation}

In the absence of statutory regulation by the state, ${ }^{119}$ an assertion of jurisdiction by state public utility commissions nnay offer an alternative to unregulated wire television expansion. The scope of a state commission's jurisdiction depends upon the statutory definition of "public utility." Statutes of some states have been construed to include wire television within the definition of public utility. ${ }^{120}$

Assumption of jurisdiction by public utility commissions is not neces-

118 It has been suggested that courts frequently prefer to find pre-emption rather than to hold a state law unconstitutional on independent grounds. The authors of this suggestion state that this technique should be used in cases where the alternative constitutional ground is based upon the negative implications of an affirmative constitutional grant of power. On the other hand, pre-emption should not be used where the alternative is an independent standard such as due process or equal protection. The finding of pre-emption should not be made in the latter instance because when and if Congress ultimately did react to a finding of pre-emption by enacting legislation, the court would then be required to decide the underlying constitutional question-which it might as well have done in the first instance. See Comment, Pre-emption as a Preferential Ground: A New Canon of Construction, 12 Stan. L. REv. 208, 225 (1959).

118 Only California has enacted a statutory scheme to regulate pay television. Prior to its repeal, Cal. Stats. ch. 5, § 1 (1st Ex. Sess. 1963) enabled pay television to operate in California and provided a means to tax it; the statute did not purport to be a comprehensive regulatory scheme. By contrast, The free television act, Cax. Crv. Code $\$ \S 43-1$ through $43-7$, is comprehensive in the extreme since it bans all forms of home subscription television.

120 E.g., Re Cokeville Radio \& Elec. Co., 6 P.U.R.3d 129 (Wyo. Publ. Serv. Comm'n 1954). See note 133 infra. 
sarily adverse to the interests of wire pay television. Some companies have actively sought, or acquiesced in, a commission's assertion of jurisdiction because of the insulation from competition that public utility regulation provides. ${ }^{121}$ Beyond that, public utility regulation is generally himited to approving reasonable rates and requiring that adequate service be furnished to the public on a nondiscriminatory basis. Regulation by the FCC of wire television would be far more comprehensive. ${ }^{122}$ For example, the FCC might be able to control the use of advertising and to limit pay television development to those areas where "free" television would not be affected adversely. ${ }^{123}$

Public utility regulation of wire television has been questioned on the ground that the anti-competitive practices fostered by utility commissions conflict with federal broadcasting policy. ${ }^{124}$ The Federal Communications Act does not give broadcasters the monopoly treatment afforded common carriers such as telephone or electric companies. ${ }^{125}$ Should wire television come within the jurisdiction of state public utility commissions, however, this new phase of the broadcasting industry would not be open to the relatively "free" competition that federal policy envisions. $^{126}$

121 See, e.g., $R e$ Cokeville Radio \& Elec. Co., supra note 120. There is apparently some reason for bcheving that cable television might charge unreasonable rates. The Chairman of the Connecticut Public Utilities Commission declared that applicants seemed to expect an excessive rate of return on their CATV investments. The Chairman was quoted as saying that if more applicants had greater knowledge about utility regulation practice and philosophy many would not pursue their applications. Broadcasting, Nov. 23, 1964, pp. 74-75.

122 The full scope of FCC regulation of airwave pay television is revealed in two rule making reports: Rules and Regulations to Provide for Subscription Television Service, 23 F.C.C. 532 (1957); Rules and Regulations to Provide for Subscription Television Service, 26 F.C.C. 265 (1959).

123 Ibid.

124 Television Transmission v. Public Util. Coinm'n, 47 Cal. 2d 82, 88, 301 P.2d 862, 865 (1956); cf. Standard Radio and Television Co. v. Chronicle Publ. Co., 182 Cal. App. 2d 293, 300, 6 Cal. Rptr. 246, 252 (1960) (uniform FCC policy desirable where state court jurisdiction over intrastate activities would necessarily affect aspects of interstate television industry).

125 FCC v. Sanders Bros., 309 U.S. 470, 474 (1940). The Court held that because the Communications Act did not recognize broadcasters as common carriers, Congress intended the field of broadcasting to remain one of free competition.

126 Although the Court in Sanders supra note 125, declared broadcasting to be a field of free competition, it nevertheless held that the question of competition between prospective applicants is not to be entirely disregarded. The Court stated that the Commission could consider whether competition impaired the ability of both stations to adequately serve a portion of the listening public. These matters were, however, distinguished from the consideration that, "if a license be granted, competition between the licensee and any other existing station may cause economic loss to the latter." Id. at 475-76. Thus, only the public interest intrudes on the natural forces of competition in this industry. See, e.g., Carroll Broadcasting Co. v. FCC, 258 F.2d 440 (D.C. Cir. 1958).

On the other hand, state public utility regulation requires a different treatunent of 
One state commission, in discussing a CATV system, attempted to discredit the monopoly objection by arguing that wire television is inherently monopolistic. ${ }^{127}$ The commission stated that since no two CATV systems have ever served the same area, no question of free competition ever existed. This analysis appears sound if limited to CATV: There is no economic imcentive for two CATV systems to compete for the same viewers since both would offer the same clioice of programs. As in the case of competing electric companies, the consumer would liave no meaningful clioice.

This analysis is not, however, entirely applicable to pay television. Competing systems could offer the viewer a varied program selection. ${ }^{128}$ Individual viewers miglit subscribe to more than one pay television service and divide their viewing time between them. The FCC lias already used its licensing power to insure that airwave pay television remains competitive. ${ }^{129}$ If wire systems are given monopoly protection, the result may be uneven development of the two types of pay television without regard to the technological advantages inherent in each. ${ }^{130}$

Some public utility statutes, such as California's, ${ }^{131}$ do not lend themselves to a finding of jurisdiction over wire television. Section 216(a) of the California Public Utility Code narrowly defines those operations deemed to be public utilities, listing the specific services covered. In Television Transmission v. Public Utilities Commission, ${ }^{132}$ the California

competition. As stated by the Chairman of the Connecticut Public Utilities Commission in connection with regulation of CATV, "in return for the privilege of having a legal monopoly, a utility must be subjected to rate regulation." Broadcasting, March 30, 1964, p. 133.

127 Re Community Television Systems, 23 P.U.R.3d 444, 449 (Wyo. Publ. Serv. Comm'n. 1958).

128 Contracts entered into by STV envision the possibility of competition from other pay television systems. Prospectus, Subscription Television, Inc., Oct. 30, 1963, p. 12 (televising of baseball games by competing pay television companies), p. 23 (telephone company's right to make equivalent facilities available for use by others in same area).

129 Rules and Regulations To Provide For Subscription Television Service, 23 F.C.C. $532,545-46$ (1957). In a later rule making decision, the FCC declared that the public interest would not be served by permitting any individual station to acquire exclusive contractual or franchise riglits in any local area. Contracts must provide that any other local stations may, upon request, obtain the same terms and conditions as are set out in the contract with the applicant station. Rules and Regulations to Provide for Subscription Television Service, 26 F.C.C. 265, 269 (1959). Compare with these regulations STV's exclusive licensing agreement with Skiatron Electronics \& Television Corporation for use of patents in airwave and wire pay television. Prospectus, Subscription Television, Inc., Oct. 30, 1963, p. 11.

130 See notes 15-23 supra and accompanying text for a discussion of the technical advantages and disadvantages of each system.

131 See Cax. Pub. UtII. Code § 216(a).

13247 Cal. 2d 82, 301 P.2d 862 (1956). 
Supreme Court stated that a CATV system could be deemed a public utility only if it were held to be the equivalent of a "telephone corporation"-a service included in the Code. The court then held that television broadcasts by wire are not in the nature of a telephone service; the mere use of telephone lines, poles, conduits and facilities does not constitute "telephone communication." The court distinguished telephone service from television service on the ground that

community television antenna is not operated "in connection with or to facilitate communication by telephone" or "in connection with or to facilitate communication by telegraph" as those words are commonly understood, but simply to enable subscribers to receive television broadcasts that might otherwise be inaccessible to them. ${ }^{184}$

Notwithstanding Television Transmission, the California Citizens Committee For Free TV, in a brief filed with the California Public Utilities Commission, urged the Commission to assert jurisdiction over STV, the California subscription television corporation. ${ }^{135}$ The Committee attempted to distinguish Television Transmission on the ground that the decision dealt only with CATV systems. The Commission, however, refused to take jurisdiction over pay television and restricted itself to approval of the contracts between the telephone company, a state public utility, and Subscription Television. ${ }^{136}$ Although passage of the California

133 Id. at $86-87,301$ P.2d at 864 . Other states have reached different conclusions. The Arizona Public Utilities Commission requested an opinion fron the Attorney General on whether it had jurisdiction of CATV. The Attorney General replied that cable television was not a teleplone service as contemplated by the Arizona constitution or statutes. 1954/1955 Ops. ATT'Y GEN. 240. On the basis of a statute similar to California's, the Attorney General of Utah at first rendered an opposite opinion on the ground that the novelty of cable television is no loop-hole to the statute, Op. No. 51-108, July 31, 1951, then reversed himself on the basis of Television Transmission, Op. No. 56-129, Nov. 8, 1956. The Wyoming Public Service Commission took jurisdiction of CATV on the basis of a broadly worded statute: Public utility was defined as facilities for the transmission of intelligence by electricity. Re Cokeville Radio \& Elec. Co., 6 P.U.R.3d 129, 133 (Wyo. Publ. Serv. Comm'n 1954). The California Supreme Court in Television Transmission recognized that a difference in statutory language could have produced a different result and cited the Cokeville case as an example. Id. at 88, 301 P.2d at 866.

134 Television Transmission v. Public Util. Comm'n, 47 Cal. 2d 82, 87, 301 P.2d 862,865 (1956).

135 Brief of Citizens' Committee For Free TV, April 10, 1964, p. 5, Application of the Pacific Tel. \& Tel. Co., Application No. 46193, Calif. Public Utilities Comm'n., Feb. 11, 1964.

136 Application of the Pacific Tel. \& Tel. Co., supra note 135. Although many states have been reluctant to assert public utility regulation of CATV, to some extent many state public utility commissions lave taken an interest in regulating the relationship between the teleplione company (whose facilities are necessary to cable television) and the cable television company. See, e.g., Independent Theatre Owners v. Arkansas Publ. Serv. Comm'n, 235 Ark. 668, 361 S.W.2d 642 (1962); Re New York Tel. Co., 34 P.U.R.3d 115 (N.Y. Publ. Serv. Comin'n 1960). 
initiative moots the question whether the Commission has jurisdiction, the question may revive if the statute is declared unconstitutional. ${ }^{137}$

\section{Local Regulation}

The possibility of regulation of wire television by municipal authorities must also be considered by pay television promoters. Installation of a wire television system depends upon the use of telephone facilities. By statute, California telephone companies are granted primary state franchises and riglits to eminent domain solely for the purpose of establishing "telephone service."138 These rights of the telephone companies may not extend to the installation of a subscription television service. Before the question of pay television service arose in California, the California Supreme Court had occasion to consider whether wire television was an advanced form of telephony. ${ }^{139}$ The court took the view that primary state franchises given to telephone corporations did not include transmission of the image phase of television programs, with the consequence that any use of telephone facilities for the installation of wire television would be subject to municipal franchise regulation. Perhaps with this decision in mind, STV successfully lobbied for the enactment of a statute granting a primary state franchise to pay television systems. The repeal of this statute by the 1964 imitiative-which also outlawed home subscription television-once again places wire television franchise licensing in the hands of municipal government; most such systems are, however, prohibited by the initiative. The use of an airwave system, however, would sidestep any confrontation with local authority.

Local regulation may, however, run afoul of state constitutional or statutory provisions restricting the competence of local governments to matters of mumicipal concern. This result could come about in either of two ways. First, local regulation might be held to be expressly or impliedly pre-empted by a state statutory or regulatory scheme which encompasses wire subscription television. ${ }^{140}$ In California, the repeal by initiative of the statute regulating pay television leaves little room for local authority to act with respect to wire subscription television.

Second, municipal regulation of wire subscription television might be held to fall outside the "home rule" powers of local governments. ${ }^{141}$ The

137 See notes 2, 3 supra and accompanying text.

138 Cat. PUB. UTrL. CODE $\S 7901$.

139 Pacific Tel. \& Tel. Co. v. City of Los Angeles, 44 Cal. 2d 272, 282 P.2d 36 (1955).

$140 \mathrm{CAI}$. Const. art. XI, $\S 11$ (counties and cities may legislate if they do so consistently with general law); see In re Hubbard, 62 Cal. $2 d 119$ (1964), noted in 53 CALIF. L. REv. 902 (1965); note 171 infra and accompanying text.

${ }^{141}$ CAI. ConST. art. XI, $\$ \S 6,8(j)$ (city power over nunicipal affairs); CAL. Const. art. 
extent of these powers will vary from state to state, and even within a given state according to the class of city or county. ${ }^{142}$ In California, however, one could persuasively argue that a multicity subscription television system should be free from the inconsistent commands of the many municipalities in which it operates. Such a holding would prevent cities from imposing discriminatory taxation and regulatory burdens upon subscription television. ${ }^{143}$ Further, it is difficult to see any exclusively municipal concerns that need to be served by municipal regulation of subscription television.

\section{III}

\section{CONSTITUTIONAL IMPLICATIONS OF THE CALIFORNIA INITIATIVE}

Passage of the California initiative, together with the determination of subscription television promoters to keep pay television alive in California, ${ }^{144}$ has resulted in placing the validity of a statutory prohibition of pay television squarely at issue before the courts. The California statute raises constitutional questions under the commerce clause, the supremacy clause, the due process and equal protection clauses of the fourteenth amendment, and the freedom of speech guarantee of the first aniendment.

\section{A. The Commerce Clause}

A state prohibition of pay television inevitably imposes some burdens on the flow of interstate commerce. Enactment of the California statute imposes burdens of two kinds: (1) Programs originating in other states may not be sold to subscribers im California; and, (2) pay television stations located im other states may not broadcast, on a subscription basis, to customers located within California. Consequently, California's attempt to prohibit pay television may be challenged on the ground that it conflicts with the negative implications of the Constitution's delegation to Congress of the power to regulate interstate commerce. ${ }^{14 \mathrm{~V}}$ The cases indicate that if a state's assertion of power impinges upon interstate cominerce, the state provisions will be overturned if they discriminate

XI, § 7I/2 (county power over county affairs); see Note, 53 CaIT. L. REv. 902, 907-10 (1965); cf. CaL. Const. art. XII, § 23.

142 See Peppin, Municipal Home Rule in California: I, 30 CarrF. L. Rev. 1 (1941).

143 See generally Sato, Municipal Occupation Taxes in California: The Authority to Levy Taxes and the Burden on Intrastate Commerce, 53 Carm. L. REv. 801 (1965).

144 This determination is evidenced by the lawsuit brought to declare the free television act unconstitutional. See Weaver v. Jordan, No. 155760, Sacramento County Super. Ct., May $19,1965$.

145 U.S. Consr. art. 1, § 8. See generally Stern, The Commerce Clause and the National Economy, 1933-1946 (pts. 1, 2), 59 HARv. L. REv. 645, 59 HARV. L. Rev. 883 (1946). 
against ${ }^{146}$ or place an undue burden ${ }^{147}$ on interstate commerce or if a uniform federal policy is necessary to the free flow of trade. ${ }^{148}$

The Califorma statute does not, by its terms or effect, grant an advantage to local busmess over interstate business. The statute's preference of commercial television, CATV, and theater television does not turn upon the source-within or without the state-of the commerce. ${ }^{149}$ On the contrary, commercial television and theater television may be substantially less local in nature than subscription television. ${ }^{150}$ That the statute does not erect barriers against products produced in other states in order to protect local industry distinguishes it from legislation found to discriminate against interstate commerce. ${ }^{151}$

The burdens on commerce imposed by the California imitiative are incidental to the state's assertion of power over the sale of television services to California citizens. ${ }^{152}$ Since it does not affect other aspects of the television industry, the California statute does not inhibit broadcasting in other states. Nor does it impose duties conflicting with those imposed by other states. ${ }^{153} \mathrm{An}$ airwave pay television business conducted in a nearby state can comply with the California statute merely by not installing decoders and billing devices on television sets within California. A broadcaster using the closed circuit system is forced only to refrain from hooking up California viewers. The burdens imposed can be readily distinguished from attempts to hicense or impede the flow of goods through a state by statutes affecting interstate truckers or railroads. ${ }^{154}$ Further, the Supreme Court has indicated that television is not a subject which "inherently" requires national supervision. ${ }^{155}$ Since the statute operates at the point in the flow of commerce where the state's interest is greatest and where the effect on the nationwide flow of commerce is

\footnotetext{
146 E.g., Dean Milk Co. v. City of Madison, 340 U.S. 349 (1951).

147 E.g., Bibb v. Navajo Freight Lines, Inc., 359 U.S. 520 (1959); Buck v. Kuykendall, 267 U.S. 307 (1925).

148 Southern Pac. Co. v. Arizona ex rel. Sullivan, 325 U.S. 761 (1945); Stern, supra note 145 , at $946-47$.

149 CAI. Crv. Code $\$ \S 43-2,43-3,43-4$; cf. Memphis Steam Laundry Cleaner, Inc. v. Stone, 342 U.S. 389, 394-95 (1952); Welton v. Missouri, 91 U.S. 275 (1876).

160 Most of the closed circuit theater television programs have been national hookups of professional boxing and other athletic events. 151 Cf., e.g., Dean Milk Co. v. City of Madison, 340 U.S. 349 (1951). 152 See, e.g.s Huron Portland Cement Co. v. City of Detroit, 362 U.S. 440 (1960); Breard v. City of Alexandria, 341 U.S. 622, 633-41 (1951).

153 See Bibb v. Navajo Freight Lines, Inc., 359 U.S. 520 (1959); Southern Pac. Co. v. Arizona ex rel. Sullivan, 325 U.S. 761 (1945).

154 See Bibb v. Navajo Freight Lines, supra note 153 ; Southern Pac. Co. v. Arizona ex rel. Sullivan, supra note 153; Buck v. Kuykendall, 267 U.S. 307 (1925).

155 See Head v. New Mexico Bd. of Examiners, 374 U.S. 424 (1963).
} 
least, ${ }^{156}$ it is unlikely that the statute will be said to unduly burden interstate commerce.

\section{B. The Supremacy Clause}

As indicated earlier, where federal legislation has occupied a field of regulation, state statutes otherwise valid are unconstitutional under the supremacy clause if there is found "such actual conflict between the two schemes of regulation that both cannot stand in the same area . . ."167

The federal government may have occupied the field of pay television airwave broadcasting by issuing licenses on a test basis in $1959 .{ }^{158}$ In any event, California's passage of a pay television ban so conflicts with the FCC's licensing practices that, so far as airwave broadcasting is concerned, both schemes of regulation cannot stand in the same area. It seems clear that the California prohibition, insofar as it applies to airwave pay television, is invalid. But, as indicated earlier, ${ }^{160}$ the California ban is probably not invalid on pre-emption grounds insofar as it apphes to wire subscription television. While this discriminatory result may argue for FCC entry into the wire television field, it is but consistent with the FCC's current views of the limits on its jurisdiction. ${ }^{100}$

\section{Due Process}

\section{The Federal Constitution}

Fifty years ago California's pay television ban might have been struck down as unwarranted governmental interference with the right to engage in a useful busmess, and, therefore, a denial of due process of law. ${ }^{161}$ The United States Supreme Court's attitude in reviewing economic

156 See Railway Express Agency v. New York, 336 U.S. 106 (1949).

157 Head v. New Mexico Bd. of Examiners, 374 U.S. 424, 430 (1963), quoting Florida Lime \& Avocado Growers v. Paul, 373 U.S. 132, 141 (1963).

158 Subscription Television Service, 26 F.C.C. 265 (1959); see notes 46-50 supra and accompanying text.

150 Notes 78-118 supra and accompanying text.

100 But see notes 55-67 supra and accompanying text.

101 The Supreme Court's earlier attitude toward such legislation is illustrated by the 1917 case of Adams v. Tanner, 244 U.S. 590 (1917). Adarns involved an initiative passed by the people of the state of Washington making it illegal for an employment agency to collect fees from workers in exchange for supplying information leading to employment. Although the initiative left the agencies with an alternative source of revenue-collecting fees from employers- the Court felt that the law was a prohibition rather than a regulation of the business. The Court noted that to act as a paid agent for those seeking workers rather than those seeking work would be another and different service. "To say ... [the business] is not prohibited because fees may be collected for something done in bchalf of other principals is not good reasoning. The statute is one of prohibition, not regulation. 'You take iny house when you do take the prop that doth sustain my house; you take my life when you take the means whereby I live." "Id. at 593.

The initiative declared that the welfare of the state and its workers demanded that they be protected from conditions which would result in workers being "liable to imposition and 
legislation said to deny substantive due process has, however, undergone a pronounced change since then. The Court is today reluctant to interfere with legislative judgments involving economic regulation. A recent leading case $^{162}$ well states the Court's current view: "The day is gone when this Court uses the Due Process Clause of the Fourteenth Anendment to strike down state laws, regulatory of business and industrial conditions, because they might be unwise, improvident or out of harmony with a particular school of thought."103 Subsequently, in 1963, the Court added:

Unquestionably there are arguments showing that the [regulated] business has social utility, but such arguments are properly addressed to the legislature, not to us. We refuse to sit as a "superlegislature ...." Nor are we able or willing to draw lines by calling a law "prohibitory" or "regulatory." Whether the legislature takes for its textbook Adam Smith, Herbert Spencer, Lord Keynes, or some other is no concern of ours. ${ }^{104}$

Guided by this philosophy the Court has refused, in economic due process cases, to inquire into the reasonableness of a statute or to consider the less oppressive alternatives which may have been available to the lawmaker. To uphold the legislation, it is no longer necessary to prove that the statute actually bears a rational relationship to the lawmaker's objectives. $^{165}$ Judicial review ends with ascertaining what abuses the legislature "may have" had in mind ${ }^{100}$ and deciding whether "it might be thought that the particular legislative measure was a rational way to correct it . ..."107

extortion." Id. at 591. These abuses, said to be inherent in employee-financed agencies, may have justified proper regulation, but this was "not enough to justify destruction of one's right to follow a distinctly useful calling in an upright way." Id. at 594.

Under the Adams standard the California initiative prohibiting the charging of fees for television in the home would be unconstitutional. A statute banning subscriber financed television is obviously a prohibition of a business; the activity prohibited is not, under the Adams view, inherently immoral or dangerous to public welfare, id. at 593-95; the grounds asserted to justify the prohibition must be considered speculative; and regulation short of prohibition is probably feasible. Other cases in which the Supreme Court struck down state social and economic legislation include Tyson \& Brother v. Banton, 273 U.S. 418 (1927); Weaver v. Palmer Bros., 270 U.S. 402 (1926); Jay Burns Baking Co. v. Bryan, 264 U.S. 504 (1924); Adkins v. Children's Hosp., 261 U.S. 525 (1923); Coppage v. Kansas, 236 U.S. 1 (1915).

162 Williamson v. Lee Optical, Inc., 348 U.S. 483 (1955).

163 Id. at 488 .

164 Ferguson v. Skrupa, 372 U.S. 726, 731-32 (1963).

165 The extent to which the Supreme Court has carried its policy of deference is illustrated by the following statistic: "The Supreme Court reports reveal not a single case in the last 26 years in which the court has struck down economic legislation as violative of 'substantive' due process, either under the Fifth or Fourteenth Amendments." LockEART, Kamisar \& Choper, Cases on Constrtutional Law 611-12 (1964).

160 The Supreme Court in Williamson v. Lee Optical, Inc., 348 U.S. 483 (1955), listed a number of conclusions which "might have" been drawn by the legislature which would have explained the reasoning behind the terms of the statute. $I d$. at 487-88.

107 Id. at 488. 
A number of objectives related to the public welfare ${ }^{108}$ might have motivated California's passage of the law. Under the Supreme Court's present standard, there is no necessity of showing either that the threat the anti-pay television voters feared-destruction of free televisionwould have materialized or that the prohibition was the least oppressive means of avoiding that danger. It is sufficient to show that the lawmakers might have felt that pay television would endanger commercial television and that a prohibition was one rational way to avoid that consequence. Nor is the prohibition rendered invalid because its passage was the result of influences exerted by special interest groups; ${ }^{100}$ the motives behind legislation are considered irrelevant to a determination of the law's validity. ${ }^{170}$

Had California's statute been enacted by the legislature, the Supreme Court's policy of deference would seem to foreclose further consideration of due process objections. The ban was enacted not by the legislature, however, but by the people. The issue thus raised is whether the deference normally accorded legislative judgments on economic matters will be accorded to a judgment by the populace. The issue is particularly relevant here because the California initiative expressly repealed a legislative enactment-passed only one year earlier by a nearly unanimous voteauthorizing the development of pay television. ${ }^{171}$ The repealed statute

108 The initiative was purportedly designed to "protect" "free" television from replacement by pay television and thus to ensure that viewers, particularly those in lower economic classes, would not have to pay directly for television. A secondary purpose, not particularly emphasized in arguments to voters, was to stop an enterprise which had avoided federal regulation and was to be, therefore, "unregulated within a regulated industry." From an interview with Mr. Don Belding, California State Chairman of the Citizens Committee for Free TV. New York Times, Aug. 17, 1964, p. 51, col. 4.

169 The primary inpetus for the California initiative and most of the financial backing for "Citizens Committees for Free TV" came from theater owners and theater-affiliated individuals. According to Broadcasting Magazine, "every theater in the state, at every show, used screen ads urging the patron to vote for [the prohibition] ...." Broadcasting, Nov. 9, 1964, p. 23.

170 Damel v. Family Security Life Ins. Co., 336 U.S. 220 (1949). But see State Bd. of Dry Cleaners v. Thrift-D-Iux Cleaners, Inc., 40 Cal. 2d 436, 254 P.2d 29 (1953), in which the court thought it relevant that a minimum price statute for the dry cleaning industry was passed "for the private advantage of a small group," id. at 444, 254 P.2d at 32, and that "the asserted objective of ... the statute ... [is] not in fact [its] . . real objective." Id. at 44I, $254 \mathrm{P} .2 \mathrm{~d}$ at 34 . The court, invalidating (by a 4-3 vote) on substantive due process grounds a regulatory scheme which was designed to maintain minimum prices and which was to be administered by the dry cleaning industry itself, was evidently concerned with the special interest character of the legislation.

171 The statute, a part of the California Revenue and Taxation Code, provided, inter alia: "A subscription television [defined in Revenue and Taxation Code $\$ 35001(\mathrm{~b})$ to mean a closed circuit television system which could be received only by subscribers] corporation shall have authority to engage in the subscription television business in this State . . . " REv. \& TAX CODE $\S 35002$. Section 35003 levied a $1 \%$ gross receipts tax to be collected by the 
reflected, among other things, the sentiment that evaluation of the impact of pay television on commercial television would be premature. ${ }^{172}$ In overruling the legislature, the voters apparently rejected that view, or at least manifested unwillingness to permit a test of that impact.

In deferring to lawmakers in due process cases, the Supreme Court has never expressed a distinction between laws enacted by the, legislature and those passed by initiative. The relevant decisions have concerned legislative enactments and have been couched in terms of deference to the "legislature."

Determining whether the deference normally accorded the legislature in economic due process cases will be accorded the people requires consideration of the philosophy underlying deference. If the policy of deference be grounded in an assumption that the legislature is more competent than the courts to evaluate economic and social legislation because of the legislature's investigative opportunities and more flexible machinery for resolving economic regulatory problems, then the policy seems mapplicable to laws passed by mitiative. Special competence cannot be assumed to exist when law is made by an electorate lacking the benefits of investigation and rational study. Under those circumstances, the court would seem obligated to review both the wisdom of the enactment and the reasonableness of the counection between the problem and the solution.

If, on the other hand, the courts' policy of restraint is based upon a judgment that the philosophy of representative constitutional government interdicts judicial intervention in the process of enacting social and economic legislation and vests this authority with the people and their representatives, a statute passed by initiative should be accorded the same respect as that given a legislative enactment.

The latter rationale of the policy of deference seems to offer both a more plausible explanation of the Supreme Court's reasoning and a more workable methodology. First, the courts have implied that while notions of relative competence may play a part in the decision to defer, a more fundamental reason is that the due process clause is not predicated upon

state as well as an additional $1 \%$ to be paid to local governments within which the system was operating.

172 In 1961, the Califorma Assembly Interim Committee on Public Utilities and Corporations expressed the opinion that any legislation would be premature: "There are no pay television concerns presently operating in the State of California. This committee believes that until experience is gained from actual operations it is impossible to determine the extent of and requirement for legislation. Any attempt to draft legislation at this time, is, in

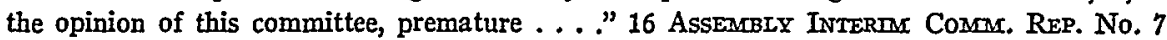
(1961).

173 "We have returned to the original constitutional proposition that the courts do not substitute their social and economic bchefs for the judgment of legislative bodies, who are elected to pass laws." Ferguson v. Skrupa, 372 U.S. 726, 730 (1963). 
a particular economic theory. ${ }^{174}$ The final decision on such questions is reserved to the people: "For protection against abuses by legislatures the people must resort to the polls, not to the courts."175 Second, delineation and application of criteria for determiming the rationality of legislation are tasks not yielding to anny easy formula; where only economic regulation is involved, the courts are understandably reluctant to interfere. ${ }^{176}$ Moreover, the judicial task of evaluating the rationality of the legislature's judgment is multiplied a thousandfold in cases of lawmaking by popular ballot. Because there is little "legislative history" to assist in ascertaining the evils an initiative was intended to meet, the rationahity of the connection between problem and remedy is hardly determinable. Courts will be, if anything, less inclined to second guess the people than the legislature. Finally, while a legislature may generally be presumed to act with greater competence than the people, this presumption seems an inadequate basis for a per se policy of greater deference to the legislature. Either body may, on occasion, enact irrational legislation. The court should apply a uniform policy to the review of all state laws. Consequently, the Court should, in considering fourteenth amendinent due process objections to the California initiative, defer to the judgment of the people.

\section{The California Constitution}

The due process requirement of the fourteenth annendment has connterparts in most state constitutions. ${ }^{177}$ Further, state courts may interpret the state due process provision to be more stringent than its federal counterpart; if they do so, the result is to limit still further the powers of the state government. ${ }^{178}$ Thus, a prohibition of pay television,

174 The attitude of today's Supreme Court was foreshadowed by Holmes, J., dissenting in Lochner v. New York, 198 U.S. 45, 74-75 (1905): "The Fourteenth Amendment does not enact Mr. Herbert Spencer's Social Statics."

176 Munn v. Mlinois, 94 U.S. 113, 134 (1876), quoted and reasserted in Williamson v. Lee Optical, Inc., 348 U.S. 483, 488 (1955).

176 Where individual liberties are at stake, such as in those cases involving statutes touching first amendment freedoms, the Supreme Court has overcome its reluctance to ascertain the rationality of legislation or the availability of less oppressive alternatives. The deference due legislative judgment in first amendment cases is explored in Richardson, Freedom of Expression and the Role of the Courts, 65 HARV. L. REv. 1, 43-54 (1951).

177 E.g., article $1, \S 13$ of the Cahifornia Constitution provides in part: "No person shall . . . be deprived of life, liberty, or property without due process of law . ..."

178 See Carpenter, Our Constitutional Heritage: Economic Due Process and the State Courts, 45 A.B.A.J. 1027 (1959); Paulsen, The Persistence of Substantive Due Process in the States, 34 Mann. L. Rev, 91 (1950); Note, 53 Coluar. L. Rev. 827 (1953); Comment, 18 O\#ro St. L.J. 384 (1957) ; cf. Dep't of Mental Hygiene v. Kirchner, 62 Cal. 2d 586, 400 P.2d 321, 43 Cal. Rptr. 329 (1965). Although the equal protection provisions of state and federal constitutions have generally been thought equivalent, the Court holds that irrespective 
even if constitutional by federal due process standards, might be held to violate the due process provision of a state constitution as interpreted by that state's highest court. ${ }^{179}$

The courts of California, after some initial hesitation, ${ }^{180}$ seem to have joined those states which follow the federal pattern of deference to the lawmakers in cases of substantive due process. ${ }^{181}$ In language similar to that used by the Supreme Court, the California Supreme Court has stated that economic legislation is to be tested by the courts "solely by the answer to the question is there any reasonable basis in fact to support the legislative determination of the regulation's wisdom and necessity."182 It appears, therefore, that the policy of deference to the lawmaker's judgment would forestall any due process challenge to the California initiative under either federal or state constitution.

\section{Equal Protection}

The equal protection clause of the fourteenth amendment requires that statutes treat alike all those similarly situated with respect to the purposes of the statute. ${ }^{183}$ If the purpose be to eradicate some mischief, the scope of prohibited activity nuust neither leave unpunished those who contribute to the mischief - an underinclusive classification-nor punish those who do not contribute to the mischief -an overinclusive classification. ${ }^{184}$ The test is not, however, nuechanically applied. More or less deference to the legislative classification schente will be given depending on the context. The amount of deference seems to vary according to: the goal of the regulation; the substantiality of the differences between the regulated and unregulated conduct or enterprise; the severity of the sanction applied; and the nature of the regulated activity.

The courts will, under these tests, first consider the substantiality of the state's interest in a particular goal, sucli as protecting the public from

of whether the statute concerned is valid under the federal constitution, it is invalid under the state equal protection provision.

$170 \mathrm{Few}$ state courts exercise the restraint manifested by the Supreme Court. The authors of a student note in 53 CoLvM. L. REv. 827, 832-33 (1953) found that by 1953 only three states, Kansas, Colorado, and Minnesota, had faithfully echoed the attitude of the Supreme Court in economic due process cases.

180 See State Bd. of Dry Cleaners v. Thrift-D-Lux Cleaners, Inc., 40 Cal. 2d 436, 254 P.2d 29 (1953); note 170 supra.

181 Consolidated Rock Prods. Co. v. City of Los Angeles, 57 Cal. 2d 515, 370 P.2d 342, 20 Cal. Rptr. 638 (1962), appeal dismissed, 371 U.S. 36 (1962).

182 Id. at 522, 370 P.2d at 346, 20 Cal. Rptr. at 642.

183 Yick Wo v. Hopkins, 118 U.S. 356 (1886). See generally Tussman \& tenBroek, The Equal Protection of the Laws, 37 CALIF. L. Rev. 341 (1949).

184 See Korematsu v. United States, 323 U.S. 214 (1944); Hirabayashi v. United States, 320 U.S. 81 (1943); Tussman \& tenBroek, supra note 183, at 347-53. 
unskilled opticians, ${ }^{185}$ or eliminating the danger of fire in laundries. ${ }^{180}$

Second, the courts will ask what relevance the classification has to the legislative purpose. ${ }^{187}$ Some classifications, such as race, are considered inherently impermissible. ${ }^{188}$ Some, such as sex, may be permissible for some purposes, such as determining who shall be allowed to work more than eight hours per day, ${ }^{189}$ but impermissible for others, such as determining which voters shall be taxpayers. ${ }^{190}$

The third element is the severity of the sanction applied. The more severe the consequences attached to particular proscribed conduct, the more sure the state must be that it punishes all those and only those who contribute to the mischief the enactment is designed to eliminate. For example, Oklalioma's habitual criminal statute permitted sexual sterilization of those who repeatedly committed thefts, but not of those who embezzled. ${ }^{191}$ The Supreme Court held that the failure to treat similarly all those similarly situated rendered the statute invalid under the equal protection clause. Perhaps, said the court, one could discriminate between thieves and embezzlers for other purposes, such as rehabilitation programs, or sentencing; presumably, the Court's rationale was that the sanction of sentencing being less severe than sexual sterilization, the state would be allowed more judicial deference in formulating its classifications.

The fourth relevant variable is the nature of the regulated activity. In economic regulation equal protection cases, the courts have permitted the legislature great latitude in classifying. ${ }^{102}$ However, "the validity of a classification must appear clearly when a fundamental right is mvolved." ${ }^{193}$ If the right to speak, ${ }^{194}$ to pubhish, ${ }^{195}$ to vote, ${ }^{190}$ or to be represented in the state legislature ${ }^{197}$ is involved, the Supreme Court of

185 Williamson v. Lee Optical, Inc., 348 U.S. 483 (1955).

186 Yick Wo v. Hopkins, 118 U.S. 356 (1886).

187 Compare Railway Express Agency v. New York, 336 U.S. 106 (1949), with Morey v. Doud, 354 U.S. 457 (1957).

188 E.g., Goss v. Board of Educ., 373 U.S. 683 (1963); cf. Balaban v. Rubin, 14 N.Y.2d 193, 199 N.E.2d 375, 250 N.Y.S.2d 281, cert. denied, 379 U.S. 881 (1964); Fuller v. Volk, 230 F. Supp. 25 (D.N.J. 1964).

189 See, e.g. 'Muller v. Oregon, 208 U.S. 412 (1908).

190 Lyman v. Martin, 2 Utah 136 (1878).

191 Skinner v. Oklahoma, 316 U.S. 535 (1942).

192 Williamson v. Lee Optical, Inc., 348 U.S. 483 (1955); Railway Express Agency v. New York, 336 U.S. 106 (1949); Kotch v. Board of River Port Pilot Comm'rs, 330 U.S. 552 (1947); cf. Morey v. Doud, 354 U.S. 457 (1957).

193 Canon v. Justice Court, 61 Cal. 2d 446, 461, 393 P.2d 428, 436-37, 39 Cal. Rptr. 228, 236-37 (1964); see Katzev v. County of Los Angeles, 52 Cal. 2d 360, 341 P.2d 310 (1959). 184 Cf. Canon v. Justice Court, 61 Cal. 2d 446, 393 P.2d 428, 39 Cal. Rptr. 228 (1964). 195 Katzev v. County of Los Angeles, 52 Cal. 2d 360, 341 P.2d 310 (1955); cf. Grosjean v. American Press Co., 297 U.S. 233, 251 (1936).

106 E.g., Davis v. Schnell, 81 F. Supp. 872, aff'd, 336 U.S. 933 (S.D. Ala. 1949).

197 E.g., Reynolds v. Sims, 377 U.S. 533 (1964); cf. Fortson v. Dorsey, 379 U.S. 433, 440

(1965) (Douglas, J., dissenting). 
the United States and that of California have indicated that they will look closely at the classification adopted.

Applying these four variables to the free television act: (1) The pay television ban involves a state purpose to prevent monopoly and foster communication of ideas and entertainment; ${ }^{198}$ (2) to achieve that purpose the free television act distinguishes between commercial television and home subscription television, creating exemptions for educational pay television, bar, restaurant, school, or hotel pay television, and community antenna systems; $;^{199}$ (3) the sanction applied is a total ban; ${ }^{200}$ and (4) the regulated activity is a medium of communication.

One may take the view that a ban on pay television is to be tested by "economic regulation" standards-the standards applied to optical companies $^{201}$ or siguboards ${ }^{202}$-in which case the deference to state legislative judgments is great. Or, the ban on pay television may be thought to involve the "fundamental freedom" of speech. ${ }^{203}$ One must, therefore, consider the economic regulation cases separately from the "speech" cases.

\section{Equal Protection and Economic Regulation}

In cases involving economic regulation statutes, the Supreme Court has been as reluctant to sustain equal protection challenges as it has to uphold challenges on due process grounds. ${ }^{204}$ If there be distinctions between those activities subject to a statute and those excluded from coverage and if those distinctions might justify the legislature in treating the activities differently, the statute will be upheld. ${ }^{205}$

198 CAL. Crv. CODE $\S 43-2$.

189 CAL. CIv. Code $\S \S 43-3,43-6$.

200 Cad. Civ. Code $\S \S 43-3,43-4,43-5$.

201 Williamson v. Lee Optical, Inc., 348 U.S. 483 (1955).

202 Railway Express Agency v. New York, 336 U.S. 106 (1949).

203 Canon v. Justice Court, 61 Cal. 2d 446, 393 P.2d 428, 39 Cal. Rptr. 228 (1964);

Katzev v. County of Los Angeles, 52 Cal. 2d 360, 341 P.2d 310 (1959).

204 In the twenty-six year period during which no state laws were struck down on "substantive" due process grounds, in only one case did the Supreme Court invalidate economic legislation on equal protection grounds. See Morey v. Doud, 354 U.S. 457 (1957). This case involved an Tllinois statute regulating businesses issuing money orders. The statute expressly excepted the American Express Co. from its provisions because of its high financial standing and unquestioned solvency. The Supreme Court overturned the statute objecting primarily on the grounds that the statute created a closed class which would give American Express an advantage over competitors regardless of the latters' financial standing or solvency. The Court implied that the statute would have been upheld had its provisions referred to a generic category rather than a particular business entity.

205 See Ferguson v. Skrupa, 372 U.S. 726 (1963); Morey v. Doud, 354 U.S. 457 (1957); Williamson v. Lee Optical, Inc., 348 U.S. 483 (1955); Lindsley v. Natural Carbonic Gas Co., 220 U.S. 61 (1911): "When the classification in such a law is called in question, if any state of facts reasonably can be conceived that would sustain it, the existence of that state of facts at the time the law was enacted must be assumed." Id. at 78, quoted and reaffirmed in Morey v. Doud, supra at 464. 
Although the California statute discriminates in favor of commercial television, CATV, and theater pay television, reasons for the classification appear sufficient to avoid characterization as "invidious discrimination," the Court's talismanic phrase in equal protection cases involving economic matters. ${ }^{206}$ The state has preferred commercial television apparently on the ground that subscription television may ultimately put television beyond the reach of many viewers in lower economic strata. Neither CATV nor theater television pose this threat. If, therefore, the objective of protecting the pubhic's interest in "free" television is legitimate, the distinction drawn by the statute is rational and certainly not invidious. Further, in language appropriate to California's ban on pay television, the Supreme Court has rejected the proposition that the equal protection clause would be offended by legislation affecting only one specific business: "That respondent company is the only concern now affected by the statute does not, of course, mean a denial of equal protection. The statute is drawn in general terms; the company's success might well induce others to enter the business." ${ }^{207}$

\section{Equal Protection and Communication}

If the regulation of pay television be considered not a matter of economic regulation but rather a restriction of the form and content of speech, then the cases involving business regulation will not provide the test for the constitutionality of the free television act. It may be argued that freedom of speech is not an issue in the pay television controversy. Proponents of this view would say that the ban on pay television is no different from the ban on home solicitation of magazine subscriptions which the Supreme Court uplield against a free speech challenge in Breard v. Alexandria. ${ }^{208}$ Under this view, the free television act does not regulate the "content" of speech, or diminish the flow of ideas. It merely prefers one means of distribution-commercial television-to another-subscription television-in the interest of preserving commercial television. However, the ordinance in Breard did not entirely forbid solicitation of magazine subscriptions, it required only that the salesnian obtain the permission of the homeowner before coming upon his property. The protection of the homeowner against unwarranted intrusion by persistent salesmen was thus one feature of the ordinance that led the Court to uphold it. In an earlier case, Martin v. City of Struthers, ${ }^{200}$ the Court

206 See cases cited supra note 205.

207 Daniel v. Family Security Ins. Co., 336 U.S. 220, 225 n.5 (1949); cf. Morey v. Doud, 354 U.S. 457 (1957).

208341 U.S. 622 (1951).

209319 U.S. 141 (1943). In language applicable to the subscription television ban, the Court remarked: "For centuries it has been a commion practice in this and other countries for 
struck down an ordinance which totally forbade door-to-door solicitation without regard to permission.

There is a distinction between regulation of time or manner of speech and flat prohibition of speech. The citizens of Alexandria were still able to savor the Saturday Evening Post by mail subscription, or by buying it at newsstands. By contrast, there is now no way viewers can see the programs which the proponents of subscription television wish to offer. ${ }^{210}$ Thus, regulation of time, place, and manner of expression elides into prohibitory regulation of content.

Whatever view one takes of this controversy, it is surely arguable that the provisions of the free television act must meet the stricter standards imposed on classification systems used in regulation of fundamental freedoms, and that the burden is on those proposing restriction of subscription television to justify the restriction. ${ }^{211}$ What, then, are these standards?

The free television act's discriminations between home subscription television and other types of pay TV, and between commercial home subscription television and educational subscription television are arguably forbidden under the test laid down in Katzev v. County of Los Angeles. ${ }^{212}$ In Katzev, the county had prohibited the sale of crime comics to persons under eighteen years of age, finding the comics contributed to crime and delinquency. However, the ordinance did not forbid sale of crime comics based on true stories or on religious writings. Nor did it forbid newspaper crime comics. It did forbid sale of comics depicting animals doing acts which, if done by humans, would be crimes: for example, Bugs Bunny stealing carrots.

persons not specifically invited to go from home to home and knock on doors or ring doorhells to communicate ideas to the occupants or to invite them to political, rehgious, or other kinds of public meetings. Whether such visiting shall he permitted has in general been deemed to depend upon the will of the individual master of each household, and not upon the determination of the community. In the instant case, the City of Struthers, Ohio, has attempted to make this decision for all its inhabitants." Id. at 141. The Court held the ordinance unconstitutional under the first amendment, as applied to the states through the due process clause of the fourteenth amendment. Though Martin dealt with noncommercial solicitation, its holding is apposite to pay television. See Joseph Burstyn, Inc. v. Wilson, 343 U.S. 495 (1952).

210 Arguably, the most popular programs to be offered by subscription television will find their way on to commercial television. However, there is at least some evidence that some attractions which commercial television would find it financially unfeasible to present can be presented over subscription television by having the viewing audience pay directly. See notes 5-7 supra and accompanying text.

211 "The validity of a classification must appear clearly when a fundamental right is involved." Canon v. Justice Court, 61 Cal. 2d 446, 461, 393 P.2d 428, 436-37, 39 Cal. Rptr. 228, 236-37 (1964); see Schneider v. State, 308 U.S. 147 (1939); Note, 40 ColvM. L. Rev. 531 (1940).

21252 Cal. $2 \mathrm{~d} 360,341$ P.2d 310 (1959). 
The California Supreme Court found that the ordinance failed to include within the ambit of its proscription many kinds of comics which contribute as much to the evil sought to be eradicated as did the prohibited comics. Thus, the classification was underinclusive, and denied equal protection to certain of the prohibited comics. Second, the ordinance prohibited comics depicting Bugs Bunny stealing, although the connection between Bugs stealing a carrot and a child holding up a grocery store is tenuous. Thus, the classification was arguably overinclusive.

Applying this standard to the free television act, one could argue that the exemption of non-home pay television, and of CATV systems, fails to regulate competitors to commercial television which are as potent a threat to commercial television as is home subscription television.

Theater subscription television, home noncommercial television, CATV, and subscription television furnished to restaurants, bars and hotels all threaten to have, in the words of the free television act "an adverse effect on presently licensed television stations."213 Theater subscription television competes for coverage of major sports events; home noncommercial television competes for viewers with programming uninterrupted by commercial announcements; CATV puts competing "big-city" stations into areas in whicl normal reception problems would dictate that one or two presently licensed stations share the entire viewing audience; subscription television in schools, bars, restaurants, and hotels would compete for viewers with existing commercial stations. Accepting the initiative's purpose as reasonable and constitutional, the initiative, like the comic book prohibition in Katzev, may fall afoul of the equal protection clause because it fails to include within its proscription all those means of communication which contribute to the evil it seeks to eradicate.

The basic question, in evaluating whether the free television act creates an impermissibly underinclusive classification, is this: Are theater subscription television, hotel subscription television, CATV, and educational television sufficient threats to commercial television to be classified along with home subscription television as part of a group of media similarly situated with respect to the purpose of protecting commercial television? A definitive answer is beyond the scope of this Comment. One would need to amass data as to the cost of, potential service area of, and potential viewer response to each system. Certainly it is not self-evident that the exempted media pose as great a threat to commercial television as does home subscription television. The difficulty of making a rational choice as to the scope of the permissible legislative classification may lead 
courts considering the matter to seek other, more readily arguable, grounds of decision.

On the other hand, the free television act arguably creates an overinclusive classification by banning all home subscription television. Perhaps in some market areas both subscription television and commercial television can operate without harming one another. Perhaps a prohibition less inclusive than a total ban would forestall the dangers posed by home subscription television. Again, there remains the difficulty of arriving at a rational decision as to the permissible scope of the legislative classification.

Admitting arguendo ${ }^{214}$ that there is danger to commercial television, and that the state may regulate to avoid that danger, the basic choice made by the free television act-choosing commercial television over subscription television-is open to question. Is there enough imformation for the state to be able to sustain any classification system which prohibits one kind of television broadcasting and leaves the other unfettered? For some purposes, no doubt, a state or the federal government might distinguish between commercial and subscription television. Because subscription television uses public utility cables and "drop lines," a state might vahilly require that servicemen for subscription television installations have special training not required of ordinary television repairmen. Were the FCC to take jurisdiction over closed circuit subscription television, it might apply different criteria than are applied to conmercial airwave broadcasting stations. The reasons might be based on the technical differences between the two systems. ${ }^{215} \mathrm{Or}$, perhaps the FCC would prefer closed circuit license apphicants over airwave applicants in rugged terrain, where airwave television signals would be subject to interference.

Can the state, however, in pursuit of its goal of protecting the flow of infornation and entertainment, validly choose one mediunı of broadcasting over another? It has not been conclusively demonstrated that commercial television can serve viewers' needs better than subscription television. Nor has it been demonstrated that the two media will not be able to live side-by-side. While the potential of destructive competition might permit introduction of a comprehensive regnlatory scheme embracing both kinds of television, the problem foreseen by the drafters of the free television act does not, arguably, permit a ban on subscription television.

214 "Arguendo" because it may be: (1) that subscription television does not pose a danger to commercial television; and (2) that the presence of such a danger would in no event justify regulation, given the first amendment restrictions on regulation of media of communication. See National Broadcasting Co. v. United States, 319 U.S. 190, 226-27 (1943) (dictum); Near v. Minnesota, 283 U.S. 697 (1931).

215 See notes 34-77 supra and accompanying text, discussing federal regulation. 
Skinner v. Oklahoma $a^{216}$ is relevant in this context. For the purposes of sentencing, rehabilitation programs, and perhaps even custodial convenience, thieves and embezzlers can be segregated. But much more information on the distinction between various kinds of criminals is necessary to found a system of classification for the purpose of sexual sterilization. Similarly, much more information about the potential effects of pay television is necessary to found a classification system which, first, identifies the methods of communication that raise the danger of diminution of the flow of imforination, and, second, proscribes them and only them. Because this identification has not yet been made, the classification system adopted by the free television act nuust fail because a court would be unable to ascertain whether it treats alike all those similarly situated with respect to the purpose of maintaining free communication. This argument would be reinforced by reference to the exclusion from the act's prohibition of ineans of communication which arguably pose as much a threat as home subscription television. In this sense, the presence of those perhaps unwarranted exemptions makes the entire classification suspect.

Two arguments may be raised to counter this equal protection analysis. First, the state inay perhaps prefer commercial television because it is already in operation. The promoters of commercial television have made a substantial investunent in plant, equipment, and broadcasting facilities. Prior in time, goes the argument, is prior in right. In the field of licensing, courts have often said that revocation of an existing license requires that the state bear a greater burden than it must bear to justify failing to issue a license. ${ }^{217} \mathrm{~A}$ second justification for preferring commercial television might arise by analogy to the antitrust case of Union Leader Corp. v. Newspapers of New England, Inc. ${ }^{218}$ There the court said that no suit for violation of the antimonopoly section of the Sherman Act would lie because the relevant market area could support only one newspaper. The two parties would have to battle it out to see whicl one would survive to serve the area. So, it could be argued that the people of California, having expressly found that the state can support only one means of communication, decided to choose one to avoid the danger that the two coinpetitors would harm eacli other and restrict the flow of information.

216316 U.S. 535 (1942).

217 E.g., Columbia Auto Loans, Inc. v. Jordan, 196 F.2d 568 (D.C. Cir. 1952); Gilchrist v. Bierring, 234 Iowa 899, 14 N.W.2d 724 (1944); See Gellmorn \& Byse, ADMTNISTrATIVE LAW: CASES \& ComaneNTS 759-67 (4th ed. 1960).

218180 F. Supp. 125 (D. Mass. 1959), aff'd as modified, 284 F.2d 582 (1st Cir. 1960), cert. denied, 365 U.S. 833 (1961). 
These arguments are subject to several infirmities. The contest between two methods of financing television does not necessarily mean great dislocation of the existing medium even if subscription television should win out in the end. The same program production facilities can be used by both media. Airwave subscription television can use standard television broadcasting apparatus, with the minor addition of a signal scrambler. ${ }^{219}$

Second, letting competitors battle to see which shall have a monopoly, as in the Union Leader case, is a far different matter from a legislative foreclosure of competition on the basis of a priori judgments about which medium can best serve the public. Although the free television act was a choice by "the public," it was not a choice by the whole viewing public. Nor was it a choice based on actual evaluation of a subscription television system.

Third, prohibition of one means of disseminating ideas may go beyond regulation of the manner of expression; it may shut off expressions with a particular content. In a communications industry dominated by a few large firms, the innovator may be stifled. He may feel that his only chance of introducing new methods of communicating ideas and entertainment is to begin outside the established chamrels. In this sense, a "prior in time" argument or a "disruptive competition" argument may be interdicted, as a basis for regulation, by the first amendment. The first amendment argument will be pursued in the next section. Consider the first amendment consequences, however, of a legislative judgment that newsmagazines posed a threat to newspapers, and a legislative decision to ban newsmagazines. Such a decision would be clearly unconstitutional. ${ }^{220}$ The public must be allowed to choose, by accepting or rejecting, which means of communication and which ideas it wants to hear. ${ }^{221}$ This first amendment argument is here raised only to demonstrate that some counterarguments to the equal protection analysis offered above may raise other constitutional questions.

In sum, the equal protection clause provides a stringent test for legislators seeking to regulate subscription television. It may be that in the search for rational classifications, the legislature will be forced to bring commercial and subscription television into a single regulatory sclieme. This possibility, however, may be foreclosed because the FCC lias pre-

219 See note 15 supra and accompanying text.

220 See, e.g., Lamont v. Postmaster General, 381 U.S. 301 (1965); Marsh v. Alabama, 326 U.S. 501 (1946); Hague v. CIO, 307 U.S. 496 (1939); Grosjean v. American Press Co., 297 U.S. 233 (1936) ; Near v. Minnesota, 283 U.S. 697 (1931).

221 Lamont v. Postmaster General, supra note 220; cf. National Broadcasting Co. v. United States, 319 U.S. 190 (1943); notes 72-75 supra and accompanying text. 
empted regulation of commercial television, and perhaps even the field of airwave subscription television. There may, in short, be no constitutional ground the legislature can walk between denial of equal protection and federal pre-emption. This danger may itself be a further argument for federal regulation of subscription television, as pointed out above. ${ }^{222}$

\section{E. Freedom of Speech}

In addition to acting as an independent guarantee of biberty to citizens, the due process clause of the fourteentl amendment serves as a conduit through which the rights and prohibitions of the first amendment are applied against the states. ${ }^{223}$ The wide latitude given law-making bodies and the vague standards of judicial review characteristic of the due process cases disappear when legislation also collides with the principles of the first amendment. ${ }^{24}$ First amendment rights may not be infringed on slender grounds: "They are susceptible of restriction only to prevent grave and immediate danger to interests which the state must lawfully protect." 225

The first amendment protects the right of free expression ${ }^{226}$ and, as important, the right to experience the expressions of others. ${ }^{227}$ In pro-

222 See notes 34-77 supra and accompanying text.

223 Freedman v. Maryland, 380 U.S. 51 (1965); New York Times v. Sullivan, 376 U.S. 254 (1964); Josepl Burstyn, Inc. v. Wilson, 343 U.S. 495 (1952); Grosjean v. American Press, 297 U.S. 233 (1936) ; Near v. Minnesota, 283 U.S. 69' (1931); Gitlow v. New York, 268 U.S. 652 (1925).

224 West Virginia State Bd. of Educ. v. Barnette, 319 U.S. 624 (1943); accord, Smith v. California, 361 U.S. 147 (1959); Winters v. New York, 333 U.S. 507 (1948); Thomas v. Collins, 323 U.S. 516 (1945) ("The rational connection between the remedy provided and the evil to be curbed, which in other contexts might support legislation against attack on due process grounds, will not suffice. These rights rest on firmer foundation." Id. at 530.). For a discussion of the extent to which deference should be accorded to the legislative judgment in first amendment cases, see 1 EMIERSON \& Haber, Polimical \& Crvil RIGHTS IN THE UNITED STates 333 (2d ed. 1958); Richardson, Freedom of Expression and the Function of Courts, 65 HARv. L. REv. 1, 43-54 (1951).

225 West Virginia State Bd. of Educ. v. Barnette, 319 U.S. 624, 639 (1943).

226 The two first anjendment "freedoms" commonly considered in connection with broadcasting, freedom of speech and freedom of the press, have been considered together as "freedons of expression." Richardson, supra note 229 , at 2 n.1. For convenience, the protection afforded by the first amiendment to broadcasting has been referred to herein as "freedom of expression" or "freedon of speech."

227 "The right to comnunicate is a two-way concept: the right to give and the right to receive information and ideas; the right to advocate, teach and write; the right to hear, read, reply and reject. The right cannot exist without both a giver and a receiver ...." Green, The Right to Communicate, 35 N.Y.U.L. REv. 903 (1960); see Lamont v. Postmaster General, 381 U.S. 301 (1965); Marsl v. Alabana, 326 U.S. 501 (1946); Martin v. Struthers, 319 U.S. 141 (1943); Zeitlin v. Arnebergh, 59 Cal. 2d 901, 383 P.2d 152, 31 Cal. Rptr. 800, cert. denied, 375 U.S. 957 (1963); Schwartz, The Mail Musi Not Go Through-Propaganda and Pornography, 11 U.C.L.A.L. Rev. 305 (1964). 
tecting these preferred freedoms, ${ }^{228}$ the courts have been particularly outspoken in condemning "previous restraints" on freedom of speech. ${ }^{229}$ The courts have frequently struck down statutes prohibiting future publications $^{230}$ and those requiring licenses or prior administrative approval $1^{231}$ as a condition precedent to speaking or publishing.

Broadcasting, and specifically television, is a form of expression protected by the first amendment. ${ }^{232}$ The protection includes programs of entertainment: "What is one man's amusement, teaches another's doctrine." 233 Nor is the right diminished by virtue of the fact that the par-

228 Saia v. New York, 334 U.S. 558, 562 (1948); Marsh v. Alabama, 326 U.S. 501, 509 (1946) ; Thomas v. Collins, 323 U.S. 516, 530 (1945); Murdock v. Pennsylvania, 319 U.S. 105, 115 (1943).

229 Joseph Burstyn, Inc. v. Wilson, 343 U.S. 495 (1952): "The statute involved here does not seek to punish, as a past offense, speech or writing falling within the permissible scope of subsequent punishment. On the contrary, New York requires that permission to commumicate ideas be obtained in advance from state officials who judge the content of the words and pictures sought to be communicated. This Court recognized many years ago that such a previous restraint is a form of infringement upon freedom of expression to be especially condemned." Id. at 503. Near v. Minnesota, 283 U.S. 697 (1931): "In determining the extent of the constitutional protection, it has been generally, if not universally, considered that it is the chief purpose of the guaranty to prevent previous restraints upon publication." Id. at 713. See generally Emerson, The Doctrine of Prior Restraint, $20 \mathrm{LAw}$ \& CONTEMr. ProB. 648 (1955).

230 E.g., Near v. Minnesota, 283 U.S. 697 (1931).

231 Freedman v. Maryland, 380 U.S. 51 (1965) (licensing of movies before exhibition); Staub v. City of Baxley, 355 U.S. 313 (1958) (permit required to solicit membership in labor oganization; local officials could refuse after considering "character of applicant, the nature of the business of the organization" and "its effects on the general welfare of citizens") ; Thomas v. Collins, 323 U.S. 516 (1945) (labor organizer's card was a condition precedent to solicitation of membership); Murdock v. Pennsylvania, 319 U.S. 105 (1943) (ordinance required religious colporteurs to pay a license tax); Cantwell v. Connecticut, 310 U.S. 296 (1940) (ordinance required a certificate as a condition precedent to religious solicitations); Schneider v. State, 308 U.S. 147 (1939) (law against distribution of handbills); Hague v. CIO, 307 U.S. 496 (1939) (permit required for meetings in public park and distribution of printed matter); Lovell v. City of Griffin, 303 U.S. 444 (1938) (permission required from local officials in order to be permitted to land out literature). But a licensing requirement is not illegal per se. Times Film Corp. v. City of Chicago, 365 U.S. 43 (1961) (licensing of movies). A hicensing statute will be upleeld where little or no discretion is left in the lands of local officials and where the statute is narrowly defined to avoid specific evils. See the discussion in Cantwell v. Connecticut, supra at 304-0\%.

Procedural safeguards must be built into any administrative review over free speech activity. Freedman v. Maryland, supra; Kingsley Books, Inc. v. Brown, 354 U.S. 436 (1957); cf. Cantwell v. Connecticut, supra.

232 See National Broadcasting Co. v. United States, 319 U.S. 190 (1943); American Broadcasting Co. v. United States, 110 F. Supp. 374, 389 (S.D. N.Y. 1953), aff'd on other grounds, 347 U.S. 284 (1954); SuEad, Freedom of Speech by Radio and Television, cl. 2 (1959).

233 Winters v. New York, 333 U.S. 507, 510 (1948); accord, Joseph Burstyn, Inc. v. Wilson, 343 U.S. 495 (1952). 
ticular expression is a commercially marketable product published for profit. ${ }^{234}$

Broadcasting, however, possesses one characteristic distinguishing it from other media of expression: the limited number of available broadcasting frequencies. Uncontrolled broadcasting could produce conflicting siguals that would preclude anyone from receiving an intelligible signal. Both the opportunity to broadcast effectively and the opportunity to hear can be protected only by regulation which limits to a few the privilege of transmitting. ${ }^{235}$ Consequently, the FCC has been given the responsibility of furthering broadcasting by allocating frequencies to those applicants best quabified to serve the "public interest." licensing entails the sort of previous restraints on expression that are generally disfavored, those restraints are justified by the nature of broadcasting itself. ${ }^{237}$ Even indirect content control whicli would be readily overturned in other areas of speech or press is, to some extent, permitted under the Communications Act. ${ }^{238}$ For example, the courts have upheld the demial of a broadcasting license for attacks on the Cathohic Church, ${ }^{2 a 0}$ while, in another context, a statute prohibiting sacrilegious movies has been struck down. ${ }^{240}$

234 Smith v. California, 361 U.S. 147, 150 (1959): "It is of course no matter that the dissemination takes place under commercial auspices. See Joseph Burstyn, Inc. v. Wilson, 343 U.S. 495 (1952); Grosjean v. American Press, 297 U.S. 233 (1931). Certainly a retail book seller plays a most significant role in the process of the distribution of books." In Near v. Minnesota, 283 U.S. 697 (1931), the court commented: "Characterizing the publication as a busmess, and the business as a nuisance, does not permit an invasion of the constitutional immumity against restraint." Id. at 720. The Supreme Court in New York Times v. Sullivan, 376 U.S. 254 (1964), re-emphasized the distinction between "purely commercial advertising" which could be regulated and the communication of information in the form of an advertisement which was a protected activity. Compare Schneider v. State, 308 U.S. 147 (1939), with Valentine v. Chrestensen, 316 U.S. 52 (1942); cf. Cantwell v. Connecticut, 310 U.S. 296 (1939), in which the Supreme Court stated that a state could not prevent the collection of funds for a religious purpose by unreasonably obstructing or denying their collection.

235 National Broadcasting Co. v. United States, 319 U.S. 190, 226-27 (1943); FCC v. Sanders Bros. Radio Station, 309 U.S. 470 (1940); Trinity Methodist Church, South v. Federal Radio Comm'n, 62 F.2d 850 (D.C. Cir. 1932).

236 National Broadcasting Co. v. United States, 319 U.S. 190 (1943), construing 48 Stat. 1082, 1083 (1934), as amended, 47 U.S.C. $\$ \$ 303,307$ (1964).

287 "Freedom of utterance is abridged to many who wish to use the limited facilities of radio. Unlike other modes of expression, radio inherently is not available to all. That is its umique characteristic, and that is why, unlike other modes of expression, it is subject to governmental regulation. Because it cannot be used by all, some who wisb to use it must be denied." National Broadcasting Co. v. United States, 319 U.S. 190, 226 (1943). 238 See note 76 supra and accompanying text.

239 Trinity Methodist Church, South v. Federal Radio Commission, 62 F.2d 850 (D.C. Cir. 1932).

240 Joseph Burstyn, Inc. v. Wilson, 343 U.S. 495 (1952). 
Notwithstanding these limitations, the Communications Act is designed as a safegnard over the availability of broadcasting to the publicnot as a device for government control of speech. ${ }^{241}$ Yet the extent to which the first amendment has been relaxed in broadcasting cases never has been clearly expressed by the courts. The cases seem to indicate, however, that whether a prohibition of pay television is constitutional under the first amendment depends upon the relationship between two components: the extent to which the prohibition abridges a first amendment freedom and the extent to which characteristics peculiar to the activity, in liglit of the state's interest in enacting the statute, tend to justify the abridgment. ${ }^{242}$

The financing of expression forms an integral part of the commumication. Newspapers, movies, and broadcasting may be subjected to taxes similar to those imposed on other businesses, but taxes calculated to himit "circulation" are unconstitutional. ${ }^{243}$ The Supreme Court las lield that a tax aimed specifically at advertising revenue violates the first amendment because, if increased, it could destroy the source of revenue, resulting in interference with the communication itself. ${ }^{244}$ It should follow that a measure designed to eliminate any source of revenue to support protected communication would be equally objectionable.

The restraint imposed by California's ban on pay television is not mitigated by the availability of alternative methods of communicating or of financing communication. The riglit to choose a particular method may be as important as the right to communicate; characteristics peculiar to that inethod may make it preferable to others. ${ }^{245}$ Consequently, the

241 "But Congress did not authorize the Commission to choose among applicants upon the basis of their political, economic or social views, or upon any other capricious basis." National Broadcasting Co. v. United States, 319 U.S. 190, 226 (1943) (dictum).

242 For a general discussion of the factors involved in determining the legality of a first amendment restraint, see Richardson, supra note 229 ; cf. Brennan, The Supreme Court and the Meiklejohn Interpretation of the First Amendment, 79 HARv. L. REv. 1 (1965).

243 Grosjean v. American Press Co., 297 U.S. 233, 250 (1936) (dictum) ; Corona Daily Independent v. City of Corona, 115 Cal. App. 2d 382, 252 P.2d 56, cert. denied, 346 U.S. 833 (1953).

Nor are businesses which engage in first amendment activities immune from other regulatory measures which apply equally to all businesses. E.g., Oklahoma Press Publ. Co. v. Walling, 327 U.S. 186 (1946) (Fair Labor Standards Act); Associated Press v. Umited States, 326 U.S. 1 (1945) (Sherman Act); Associated Press v. National Labor Relations Board, 301 U.S. 103 (1937) (National Labor Relations Act).

244 Grosjean v. American Press Co., 297 U.S. 233 (1936); City of Baltimore v. A. S. Abell Co., 218 Md. 273, 145 A.2d 111 (1958).

245 Talley v. California, 362 U.S. 60,64 (1960) ("without the circulation, the publication would be of little value"); Schwartz-Torrance Inv. Corp. v. Bakery \& Confectionery Workers Umion, 61 Cal. 2d 766, 394 P.2d 921, 40 Cal. Rptr. 233 (1964); Wollam v. City of Palm Springs, 59 Cal. 2d 276, 379 P.2d 481, 29 Cal. Rptr. 1 (1963). 
courts have seldom considered whether alternative means are available in deciding the validity of a restraint on one method. Speech by sound truck is considered to be distinct from amplified speech in a public park; ${ }^{243}$ restraints on the distribution of handbills are not evaluated against the alternative of mailed circulars. ${ }^{247}$ Language used by the California Supreme Court in a "sound truck" case seems apposite: "In certain instances the sound truck may be the only practical means for communication of opinion; alternative modes of communication, such as radio or television, may be prohibitively expensive, not available, or not effective." ${ }^{248}$ One cannot demonstrate that the financial structure of the commercial television industry precludes transmission of specific types of programs-those without a broad base of popular appeal-yet experience tends to confirn that view. ${ }^{249}$ A prohibition of pay television may directly prohibit expression of some ideas or messages. Unfortunately, the assertion that pay television can, and will, provide programs unavailable on commercial television has, in large part, been rendered unverifiable by the Cahifornia prohibition. It seems reasonable to place upon the state the burden of showing that no loss to society-in the form of otherwise uncommunicated ideas or entertaminent-will occur as the result of banning pay television. ${ }^{250}$

This conclusion is reinforced by Schneider $v$. State. ${ }^{251}$ There the state sought to justify an antileafleting ordinance on the ground that leaflets littered the streets. The Court adverted to alternative means of suppressmg littering, and indicated that the state must explore these before considering a restraint on speech. ${ }^{262}$ Moreover, the state may have to be content with a less efficient alternative means to suppress an evil brigaded with protected speech; this inefficiency is the price one pays for free communication. ${ }^{253}$ So in the field of pay television the state may have to

246 E.g., Kovacs v. Cooper, 336 U.S. 77 (1949); Sain v. New York, 334 U.S. 558 (1948); Wollam v. City of Palm Springs, supra note 245.

247 E.g., Talley v. California, 362 U.S. 60 (1960); Martin v. Struthers, 319 U.S. 141 (1943); Lovell v. City of Grifin, 303 U.S. 444 (1938).

248 Wollam v. City of Palm Springs, 59 Cal. 2d 276, 284, 379 P.2d 481, 486, 29 Cal. Rptr. 1, 6 (1963).

249 Indeed, this is said to be one of the reasons for the interest in the development of pay television. See the speech delivered by John H. Pinto, Vice President of RKO General Phonevision Company, before the Hollywood Advertising Club, Hollywood, California, March 16, 1964; the remarks by Mr. Pinto before the Georgia Association of Broadcasters, Atlanta, Georgia, August 4, 1964 ; Pay TV Showdown in the Making, Broadcasting, March 15,1965, p. 33.

250 See note 211 supra and accompanying text.

251308 U.S. 147 (1939).

252 Id. at 162.

253 Id. at 163-65. See generally Wormuth \& Mirkin, The Doctrine of the Reasonable Alternative, 9 UTAB L. Rev. 254 (1964). 
seek the least oppressive alternative means to deal with the evils alleged to flow from pay television.

The assertion of government power over the selection of a source of television revenue is an indirect assumption of control over the content of television broadcasts. That those providing the revenue for broadcasts currently dictate the content of programs is well known. Similarly, government power to select who shall pay implies the power to select what shall be said, what poimt of view shall be represented. This form of government control is repugnant to long estabhshed principles of the first amendment. In a medium of commumication as effective as television, the danger of content control is particularly grave. Even if the prohibition is in the mam valid, if in its breadth it steps on protected freedoms, this overbreadth will nullify the statute. ${ }^{254}$

In addition, it may be argued that the right to communicate effectively and the right to select the content of speech without government interference imply that additional content will not be forced upon the speaker by the government. ${ }^{255}$ The effect of prohibiting pay television is to perpetuate a system of programming saturated with commercial messagesfor if subscriptions are prohibited, broadcasters are forced to sell time to advertisers. Compelling broadcasters to accept commercials inhibits their freedom $\dot{m}$ two respects: commercials themselves reduce the effectiveness of any broadcast, and the compulsion thrusts upon the broadcasters content that may not be desired. The correlative of requiring broadcasters to sell time for commercials is to compel viewers to receive televised ideas only when accompanied by commercials. Simce the right to communicate is a two-way concept, including the right to receive information, facts, and ideas, ${ }^{256}$ the prohibition restricts a viewer's right to receive those ideas unadorned by unnecessary and unwanted sales appeals. Unless it is self-evident that the public interest is somehow advanced by forcing upon viewers commercials they are willing to forego, the statute is not essentially different from one allowing the public to view movies only in black and white or to hear speeches only if delivered by speakers with a specific speech impediment. These limitations on the freedom of broadcasters and viewers, while not major restrictions in themselves, add to the burdens imposed by the prohibition. The repressive effects of the statute are not essentially different from a statute prohibiting home de-

254 Fort v. Civil Service Comm'n, 61 Cal. 2d 331, 392 P.2d 385, 38 Cal. Rptr. 625 (1964); cf. Aptheker v. Secretary of State, 378 U.S. 500 (1964).

255 It is, however, established that the FCC may require a licensee to broadcast "public service" programs, "equal time" political broadcasts, and a variety of points of view on controversial issue. See note 79 supra and accompanying text.

256 See note 227 supra and accompanying text. 
livery subscriptions of magazines or newspapers-a measure which would be branded as repugnant to the first amendment by most courts. ${ }^{257}$

Granting that the California statute severely impinges upon freedom of expression, one must inquire whether there is a definite, compelling and present need for the abridgment. The objective of the statute-protection of commercial television-is based upon highly speculative premises: Both the $\mathrm{FCC}^{258}$ and the California legislature ${ }^{250}$ have expressed doubt as to the existence of grounds for concern that pay television might absorb programs from commercial television or that the former would completely replace the latter. Even if some such threat exists, the extent of the danger is not known and cannot be forecast. The amount of money spent by advertisers for television time would seem to belie the conclusion that they would be unable to compete with subscriber-financed programs.

Even where a compelling need is shown, limitations on the power to regulate are strict. Legislation designed to further some legitimate objective must be specific and narrow. ${ }^{260}$ In light of the uncertainty of the danger posed, the California statute reaches far beyond the restraint necessary to protect commercial television. ${ }^{261}$ It is not difficult to conceive of less oppressive regulatory measures which would preserve commercial television. ${ }^{262}$ The present regulatory pattern embraced by the FCC, involving experimental hicenses and cautious appraisal of the effects of experiments, is one example. ${ }^{263}$

The special characteristics of broadcasting justify regulation and warrant close supervision of the development of pay television. To grant necessity for some regulation is not, however, to conclude that prohibition is justified. While the first amendment inay not be offended by supervisory powers such as those exercised by the FCC, a prohibition, because it elimmates all the safeguards of regulation including prompt administrative and judicial review, is the most offensive of abridgments. ${ }^{204}$

257 See notes 220-21 supra and accompanying text.

258 Subscription Television Service, 26 F.C.C. 265 (1959) (FCC set up safeguards over pay television licenses until it could be ascertained whether pay television is in the public interest). FCC Commissioner Lee Loevinger has stated: "I think that the possibilitics of pay TV are nothing like those suggested by the speakers who said it would destroy conventional TV and are in fact, relatively limited. On the basis of studies which $I$ have seen, it appears to me that pay TV is a practical possibility only in a limited number of areas of concentrated urban population. At best it may be a rival of conventional TV for some programs in these areas, and at worst it will have a very difficult struggle to survive at all." Loevinger Explains His Pay TV Views, Broadcasting, Nov. 30, 1964, p. 57.

25016 Assembly Intertar Comar. Rep. No. 7 (1961).

200 See, e.g., De Jonge v. Oregon, 299 U.S. 353 (1937).

261 See notes 217-19 supra and accompanying text.

262 See notes 76-77 supra and accompanying text.

263 See notes 46-50 supra and accompanying text.

264 Compare Near v. Minnesota, 283 U.S. 697 (1931) (flat ban, prior restraint-un- 
Broadcasting is subject to some considerations and restraints not applicable to other first amendment activities, yet "the basic principles of freedom of speech and the press, like the First Amendment's command, do not vary. Those principles, as they have frequently been enunciated ... make freedom of expression the rule." ${ }^{265}$

Television and radio, like newspapers and magazines, are multimillion dollar businesses. The incentive of entrepreneurs to profit from advertising or subscriptions is the force that keeps the media in operation. "Speech for profit" makes America among the best-informed nations in the world. ${ }^{266}$ To protect from competition the entrepreneur who is already engaged in communication is to restrict the flow of information by guaranteeing one group of communicators - those already set up in business-a permanent monopoly. Commercial television is, moreover, financed by advertisers; diversity of program content may well be proinoted by a medium which is directly financed by listeners. ${ }^{267}$

Television is one of the most effective and forceful vehicles for communication in today's world; because of its nature, it must be protected for all citizens by intelligent regulation. This does not imply, however, that the first amendment yields to government control over programming content and the selection of those who shall finance the media. The first amendment guarantees a right which cannot be submitted to vote. ${ }^{268}$

\section{IV}

\section{ANTITRUST: A TWO-EDGED SWORD ${ }^{269}$}

Attempts to launch pay television operations have given rise to a variety of antitrust problems. On the one hand, the antitrust laws may

constitutional), with Beauharnais v. Tllinois, 343 U.S. 250 (1952) (a posteriori punishment -constitutional). Compare Thornhill v. Alabama, 310 U.S. 88 (1940) (fiat ban on picketing -unconstitutional), with International Brotherhood of Teamsters v. Vogt, Inc., 354 U.S. 284 (1957) (regulation of picketing-constitutional).

265 Joseph Burstyn, Inc. v. Wilson, 343 U.S. 495, 503 (1952).

268 See Joseph Burstyn, Inc. v. Wilson, supra note 265 , at 501 ; see generally IncLts, Freedodr of the Movies (1947); Klapper, The Efrects of Mass Media (1950).

267 See notes 5-7 supra and accompanying text. See generally Hma, VorUNTARY LIsTENER-SPONSORSHIP (1958).

268 West Virginia State Bd. of Educ. v. Barnette, 319 U.S. 624, 638-39 (1943).

289 There are only two major pay television promotions in the United States which can serve as a background to a discussion of these problems-one in Hartford, Connecticut and the other in Los Angeles and San Francisco, California. See, e.g., Broadcasting, March 15,1965, p. 33.

Three statutes will be referred to in this section of the Comment: the Sherman Act, 26 Stat. 209 (1890), as amended, 15 U.S.C. $\$ \S 1-7$ (1964); the Clayton Act, 38 Stat. 730 (1914), as amended, 15 U.S.C. §§ 12-27 (1964); the Federal Trade Commission (FTC) Act, 38 Stat. 717 (1914), as amended, 15 U.S.C. §§ 14-51 (1964). The Acts will be cited hereinafter by their popular names. The sections relevant to the following discussion are: 
give promoters a weapon with which to counter the tactics of anti-pay television forces; on the other hand, promoters may be subject to liability under the antitrust laws for engaging in prohibited contractual arrangeinents and corporate relationships.

\section{A. Refusal to Deal}

Pay television systems must rely on current nnovies for their main programming staple. 270 The extent of that rehance is evidenced by the vigorous opposition of theater owners and exhibitors. In fact, notwithstanding the frequently heard warning that commercial television will be destroyed if pay television becomes established, the opposition of commercial television is minor compared to that voiced by the theater interests. ${ }^{271}$ The competitive advantage vis-à-vis theater exhibitors is clear: Subscription television offers the same attractions, more convemiently, at lower prices, to larger audiences. Commercial networks are prepared to join in tapping the pay television market should it prove lucrative, ${ }^{272}$ whereas theater owners and exhibitors do not have that alternative.

Motivated by the desire for self-preservation, theater interests lave sought to eliminate this source of potentially ruinous competition. ${ }^{273}$ - While some forms of opposition have been proper, less legitimate devices have raised questions of possible antitrust violations. Theater interests

$\S 1$ of the Sherman Act, making it illegal to conspire or combine in restraint of trade; \& 2 of the Sherman Act, making it illegal to monopolize or attempt to monopolize a line of commerce or trade; $\S \S 4-5$ of the Clayton Act, which provide for civil suits by private persons; $\S 5$ of the FTC Act, making unlawful certain unfair methods of competition in interstate commerce.

270 See notes 5-7 supra and accompanying text for a discussion of pay television programming.

271 The major networks have generally restricted themselves to verbal assaults. See Networks Cool to Pay TV, Broadcasting, March 15, 1965, p. 36. There is no indication that the networks contributed funds toward the banning of pay television in California; those campaign funds were reportedly donated by organizations and individuals connected with the motion picture busimess. Broadcasting, October 5, 1964, p. 60. The Columbia Broadcasting System (CBS) has declared that while it opposes FCC licensing of pay television it does not support any movement to ban wire pay television. Broadcasting, May 11, 1964, p. 72; Broadcasting, October 5, 1964, p. 60 .

272 Broadcasting, April 6, 1964, p. 104; Broadcasting, May 11, 1964, p. 72 (statements by executives of the National Broadcasting Company (NBC) and CBS).

273 In Hartford, Conn., theater groups opposed the FCC licensing of an experimental pay system. Connecticut Comm. Against Pay TV v. FCC, 301 F.2d 835 (D.C. Cir. 1962). Appearances have also been made before state public utility commissions. See Independent Theatre Owners v. Arkansas Pub. Serv. Comm'n, 235 Ark. 668, 361 S.W.2d 642 (1962); Brief filed with the California Public Utilities Commission (San Francisco Office) by the Citizens Committee for Free TV, April 10, 1964. For background to this latter controversy, see New York Times, March 26, 1964, p. 7, col. 1. 
have been accused of organizing a boycott by film producers and distributors that has deprived pay television of access to its prime programming source. ${ }^{274}$ Although the Sherman Act provides a remedy for combinations that would restrict film purchases in the competitive market, ${ }^{275}$ problems of proof comphicate recovery.

The Sherman Act does not require a supplier to deal with every individual who might wish to buy or license his product. A mere refusal to deal based upon the exercise of independent discretion is not actionable. ${ }^{270}$ Refusals to deal do violate the Sherman Act, however, when prompted by complaints or threats of other customers and licensees ${ }^{277}$ or when they result from a common agreement among suppliers. ${ }^{278}$ Nevertheless, evidence of parallel beliavior by film producers and distributors is not of itself sufficient evidence of an agreement. ${ }^{279}$ Similarly, a showing of orgarized pressure by theater owners and exhibitors is innocuous unless there is a further showing that producers and distributors were influenced by this pressure. ${ }^{280}$ Illegal boycotts may, however, be inferred from evidence that producers and distributors were acting contrary to economic self-interest ${ }^{281}$ or that refusals to deal would not reasonably be made by one producer or distributor without the understanding that all were to join. 282

Some film producers have attempted to resist pay television distribu-

274 Interview With the General Counsel for RKO General, Inc. in New York City, August 24, 1964 (RKO General in conjunction with RKO Phonevision operated the Hartford, Conn. pay television station). By the time STV became operational in California, the major film studios were willing to supply pay television but not always on terms equal to those accorded competing movie theaters. See notes 284-87 infra and accompanying text.

275 See, e.g., Klor's, Inc. v. Broadway-Hale Stores, 359 U.S. 207 (1959) (a group of businessmen may not act in concert to deprive even a single businessman of goods he needs to compete effectively).

$270 \mathrm{~A}$ frequent example of the use of independent discretion in refusals to deal arise in cases of resale price maintenance. See United States v. Colgate \& Co., 250 U.S. 300 (1919), where the Court first held that the manufacturer may select customers in order to enforce a company policy. But see United States v. Parke, Davis \& Co., 362 U.S. 29 (1960), for a limitation on this rule.

277 Girardi v. Gates Rubber Co. Sales Div., Inc., 325 F.2d 196 (9th Cir. 1963).

278 Klor's, Inc. v. Broadway-Hale Stores, 359 U.S. 207, 212-13 (1959). The use of threats or coercion by a manufacturer to force the adoption of its policy by a customer is also disapproved. See United States v. Parke, Davis \& Co., 362 U.S. 29, 45-47 (1960).

270 See Theatre Enterprises, Inc. v. Paramount Film Dist. Corp., 346 U.S. 537, 540-41 (1954); United States v. Paramount Pictures, Inc., 334 U.S. 131, 141-48 (1948).

280 Compare Klein v. American Luggage Works, Inc., 323 F.2d 787 (3d Cir. 1963), with Girardi v. Gates Rubber Co. Sales Div., Inc., 325 F.2d 196 (9th Cir. 1963).

281 Cf. United States v. Paramount Pictures, 334 U.S. 131, 144-48 (1948); Miligrain

- v. Loew's, Inc., 192 F.2d 579, 582 (3d Cir.), cert. denied, 343 U.S. 929 (1951).

282 Interstate Circuit, Inc. v. United States, 306 U.S. 208, 223 (1939). 
tion altogether. ${ }^{283}$ Even when pay television groups have been successful in obtaining films, releases have been substantially delayed, commonly for nine months after the commencement of first run theater engagements or until releases are made to neighborhood theaters. ${ }^{284}$ Economic reasons seem to justify both delayed releases and blanket refusals to deal, at least during pay television's incipient stages. Pay systems tend to dilute the market because large numbers of persons may view the film for one low fee. If the number of subscribers were so great that volume would guarantee a lucrative return in spite of market dilution, ${ }^{285}$ producers and distributors would be acting contrary to their economic self-interest should they refuse to supply first run releases. ${ }^{286}$ The economics are comparable to those governing current theater distribution: A series of exclusive engagements at large capacity theaters followed by neighborhood theater exhibition will usually result in greater return than could be obtained by immediate distribution to all exhibitors. Because of these economic conditions, "runs" and "clearances" between theaters have been upheld against antitrust challenges. ${ }^{287}$ Consequently, similar arrangements with pay television would be difficult to oppose.

Pay television promoters are thus faced with the recurring dilemma of needing current films to attract subscribers and requiring a large number of subscribers to obtain first run films. Because proof of a concerted refusal to deal may be met by proof that greatest financial return may be obtained through a system of "runs" and "clearances" 288 antitrust suits based on "refusal to deal" allegations are unlikely to succeed so long as subscriber systems are small.

283 Although most major studios were willing to supply Hartford pay television with current films, two producers continued to refuse to deal until antitrust litigation was threatened. Interview with General Counsel for RKO General, Inc., in New York City, August 24, 1964; see Broadcasting, March 15, 1965, p. 33.

284 STV concluded a contract with United Artists which contained a nine month delay provision. The United Artist agreement further specified that films featured on pay television would not be available to free television during the year following distribution to pay television. It was also reported that subscribers were not enthusiastic over these delayed pay television releases. Wall Street Journal, July 23, 1964, p. 5, col. 2.

285 Hartford pay television obtained more favorable terms than did STV. Current films were nuade available to Hartford pay television only fifteen to sixteen days following openings in downtown theaters. These films proved to be popular with subscribers. Ibid.

286 Cf. Twentieth Century Film Corp. v. Goldyn, 328 F.2d 190, 201 (9th Cir. 1964) (runs and clearances must be justified as reasonable restraints under economic conditions). 287 See Dipson Theatres, Inc. v. Buffalo Theatres, Inc., 190 F.2d 951, 956 (2d Cir.), cert. denied, 342 U.S. 926 (1951) (defendant demonstrated that greater returns could be produced by showing all films initially at one theater in a local area).

288 E.g., ibid.; Winchester Theater Co. v. Paramount Film Distrib. Corp., 324 F.2d 652 (1st Cir. 1963) (motive for systen of runs and clearances was desire to net larger overall revenues). 


\section{B. The Free Television Act in Restraint of Trade}

The impact of antitrust laws in the hands of pay television promoters is illustrated by the action brought by STV in connection with the controversy in California. ${ }^{289}$ STV has filed a treble damage suit charging theater interests with attempting to preserve a monopoly through a political campaign designed to dissuade potential STV customers from entering into subscription contracts. ${ }^{200}$ Conceding the ostensible purpose of the campaign to be the securing of legislation, STV alleged that the actual purpose was to permit the theater group to retain exclusive rights - to the exhibition of films and closed circuit sporting events. ${ }^{291}$ STV's action falls squarely within the doctrine of Eastern Railroad Presidents Conference v. Noerr Motor Freight, Inc..$^{292}$ In Noerr, an association of Pennsylvania truckers alleged that the defendents, twenty-four railroad compamies and a publicity firm, had conspired to restram the trade im and to monopolize the long distance freight business. The complaint charged that the railroads had engaged a publicity firm to conduct a campaign against the truckers to foster the adoption and enforcement of laws destructive of the trucking business, to create an atmosphere of distaste for truckers among the general public, and to impair the relationships existing between the truckers and their customers. It was further alleged that the railroads' sole motivation was to eliminate the truckers as competitors in the long-distance freight business. The Supreme Court held that joint agreement among economic interests designed to solicit government action with respect to passage and enforcement of laws is not prohibited by the Sherman Act, even if the motive for such agreement is to secure a monopoly or destroy competition. ${ }^{293}$ The record showed no attempt by the railroads to directly persuade anyone not to deal with the truckers; all publicity was directed at the passage and enforcement of

289 Amended Complaint (Aug. 26, 1964), Subscription Television, Inc. v. Southern California Theatre Owners Ass'n, Civil 63-1521-WM, S.D. Calif. (hereinafter cited as STV Antitrust Case). Plaintiff alleged damages totalling $\$ 33,680,500$ before tripling.

200 Amended Complaint, pp. 17-18, STV Antitrust Case.

201 Ibid.

292166 F. Supp. 163 (E.D. Pa. 1958), af'd, 273 F.2d 218 (3d Cir. 1959), rev'd, 365 U.S. 127 (1961). On the basis of this case, STV's original complaint was dismissed for failure to state a claim for which relief could be granted. Order Dismissing Action (March 20, 1964), STV Antitrust Case.

293 Eastern R.R. Presidents Conference v. Noerr Motor Freight, Inc., 365 U.S. 127, 136 (1961). The plaintiffs also charged that the defendants violated the Sherman Act by circulating propaganda through committees and groups whose appearance of independence and spontaneity was a deception manufactured by defendant. The Court held that the railroads' use of third-party devices to conduct its eampaign was legally irrelevant although perhaps morally objectionable. Id. at 140-41. Thus, although anti-pay television forces in California used third-party devices, these techniques do not create the liability necessary to sustain a cause of action. 
laws. ${ }^{284}$ Available California initiative campaign literature appears to fall within the same framework. ${ }^{295}$ The Sherman Act does not prevent these attempts to secure legislation regardless of the incidental damage done to the plaintiff or of the defendants' hope that damage might occur. ${ }^{290}$ The Court noted that any different construction of the Sherman Act raised an important constitutional question: namely, whether the right to petition for the redress of grievances would be unjustifiably curtailed. ${ }^{297}$

The Court did recognize an exception, however, where a publicity campaign, ostensibly directed toward influencing government action, "is a mere sham to cover what is actually nothing more than an attempt to interfere directly with the business relationships of a competitor."208 The Noerr record, however, did not support a "sham campaign" charge.

After a dismissal by a California federal court, ${ }^{299}$ STV amended its complaint to allege that the defendants had conducted a "sham" campaign. ${ }^{300}$ The gist of STV's argnment is that the defendants knew the initiative to be "patently unconstitutional" and hence unenforceable and that the initiative was used as a subterfuge for the true purpose of undermining STV's busmess. ${ }^{301}$ On the basis of this allegation, it is argnable that the passage of the initiative was of no consequence to the defendants. It was only the campaign that was of value because the initiative, even if passed, could never be enforced.

The exception mentioned in Noerr is so narrow ${ }^{302}$ that antitrust suits resting on a "sham campaign" theory would appear to have little hope of success. The Court seemed to feel that the bitterness of the campaign and the railroad's success in obtaiming the desired legislation was in itself proof of a genuine effort to engage in political activity. ${ }^{303}$ STV's argnment that the known unconstitutionality of the initiative renders the defendants' efforts a sham is tenuous. As this Comment suggests, there is

284 Id. at 142.

205 A sampling of the defendants' campaign literature is on file in the office of the California Law Review.

296 Eastern R.R. Presidents Conference v. Noerr Motor Freight, Inc., 365 U.S. 127, 143 (1961).

297 Id. at 137-38.

298 Id. at 144.

299 Order Dismissing Action (March 20, 1964), STV Antitrust Case.

300 Amended Complaint (Aug. 26, 1964), p. 17, STV Antitrust Case. On the basis of this complaint, defendants were directed to answer so that plaintiffs would have an opportunity to prove "sham" at a trial. Hearing on Motions (Sept. 21, 1964), STV Antitrust Case.

301 Amended Complaint (Aug. 26, 1964), pp. 120-21, STV Antitrust Case.

302 See notes 293-98 supra and accompanying text.

303 Eastern R.R. Presidents Conference v. Noerr Motor Freight, Inc., 365 U.S. 12\%, 144-45 (1961). 
a genuine difference of opinion as to the initiative's constitutionality. The California Supreme Court is not likely to decide that the initiative was so patently unconstitutional that no reasonable person could have thought otherwise. Finally, even if the initiative were now shown to be unconstitutional, the plaintiff would be required to demonstrate that the defendants knew or should have known that fact. In light of the overwhelming endorsement of the initiative by California voters, ${ }^{304}$ such knowledge would be difficult to prove.

If the initiative is declared constitutional either wholly or in part, pay television promoters elsewhere must be prepared to wage similar political battles. The availability of antitrust remedies for the collusive actions of any group sponsoring anti-pay television legislation is too limited to be meaningful.

\section{Long-Term Contracts with Program Producers}

The necessity to secure quality programming lias not only caused pay television promoters to seek antitrust remedies, but may have also exposed them to antitrust attack. Preliminary studies in pay television test areas indicate that sports programs are as lucrative as first run films. ${ }^{305}$ A steady supply of popular sports attractions is practically indispensable if pay television is to be assured financial success. Because STV is the first pay system designed to operate on a large scale, it may be instructive to consider the antitrust questions raised by STV's sports procurement program.

STV has entered into exclusive fifteen-year contracts with the San Francisco Giants and Los Angeles Dodgers. ${ }^{306}$ The contracts provide that no commercial broadcaster or other pay system may televise any of the teanis' games within a radius of fifty miles from the lome stadium and give STV the right of first refusal in an extended geographic area: Northern California for televising Giant games and Southern California for televising Dodger gaines. Under certain conditions, the teams are permitted to contract with other pay systems for the presentation of gaines outside the hicensed and extended areas. The contracts specify that in the event STV fails to obtain or maintain a mininum number of subscribers over a fifteen-year period, the teams may cancel the contracts, subject to

304 See note 1 supra for vote results.

305 Hartford pay television broadcast six heavyweight championship bouts with an average of $63 \%$ of all subscribers tuned in. This compared with an average rating of $20.1 \%$ for movies, although sports programs on the whole averaged only $9.8 \%$; other sports programs, however, were not of the caliber of the boxing matches. Broadcasting, March 15, 1965, p. 33, 35.

306 Prospectus, Subscription Television, Inc., Oct. 30, 1963, pp. 11-16. 
STV's right in the first five years to avoid cancellation by payment of specified amounts. ${ }^{307}$

It is arguable that these contracts are prohibited by the antitrust statutes. ${ }^{308}$ Exclusive contracts do not violate antitrust laws unless their length or effect produces an undue restraint on trade $\mathrm{e}^{300}$ or substantially lessens competition in the line of commerce affected. ${ }^{310}$ Whether STV's exclusive contracts are illegal depends upon whether it unreasonably excludes pay and commercial television competition. ${ }^{311}$ This determination requires an analysis of the size and scope of the relevant market and the effect of STV's exclusive arrangements within the market. ${ }^{312}$

Without a detailed economic study, it is possible only to suggest what might constitute the relevant market affected by the STV contracts. It is arguable that the general hine of commerce affected embraces all televising of sports attractions. ${ }^{313}$ Within the broad market of televised sports, however, well-defined product submarkets can be identified: for example, baseball game telecasts. ${ }^{314}$ The question is whether the effects

307 The ball clubs must receive $\$ 10,000,000$ by September 30,1968 or STV will lose its options to continue the contracts. These options may be preserved, however, if STV pays the difference between the $\$ 10,000,000$ and what the clubs actually received over the previous five year period. Ibid.

308 Liability would stem principally from $\S 3$ of the Sherman Act and $\S 5$ of the Federal Trade Commission Act (which permits the FTC to prohibit competition that may violate the Sherman Act). Section 3 of the Clayton Act is probably not applicable to the contracts in question since they involve no "goods or commodities" as those terms are commonly understood. In the early stages of pay television development, it is likely that if any antitrust violations are prosecuted, the government will choose to attack the prohibited actions through the FTC Act since the possibility of unreasonable restraint is easier to demonstrate than the accomplished fact of such restraint. See, e.g., FTC v. Motion Picture Advertising Serv. Co., 344 U.S. 392 (1953).

309 Sherman Act $\S \S 1,2$.

310 Clayton Act $\S 3$.

311 Not every trade restraint is per se illegal. See White Motor Co. v. United States, 372 U.S. 253 (1963); Chicago Bd. of Trade v. United States, 246 U.S. 231 (1918). Although exclusive contracts cause varying degrees of trade restriction, it is possible to characterize some restraints as legitimate. See, e.g., Packard Motor Car Co. v. Webster Motor Car Co., 243 F.2d 418 (D.C. Cir. 1957), cert. denied, 355 U.S. 822 (1957).

312 Compare Standard Oil Co. of California v. United States, 337 U.S. 293 (1949), with Tampa Electric Co. v. Nashville Coal Co., 365 U.S. 320 (1961). It is not clear to what extent economic factors will be considered in determining what is a permissible restraint. Ibid. Although these two cases deal with Clayton Act § 3 violations, there is no reason why these tests will not equally apply to Sherman Act cases. See notes 319-20 infra and accompanying text.

313 Radio broadcasting might also be considered as part of this market. It seems, however, that radio reaches a separate market (e.g., autoniobile travel) and therefore should be excluded.

814 In United States v. E. I. du Pont de Nemours \& Co., 351 U.S. 377, 394-400 (1956), the Supreme Court stated that product markets inust be determined by examining "cross elasticity of demand" to determine whether a commodity is reasonably interchangeable by the consumer for the same purpose. This general test was more precisely defined by the 
of market foreclosure should be measured in a submarket composed of all televised baseball games in Northern and Southern California respectively, or whether the relevant product market, further subdivided, should be defined as only those televised baseball games broadcast in Northern and Southern California which feature Cahifornia teams. ${ }^{315}$ Regardless of which category is used, STV has secured a significant portion of the market. Except for occasional network telecasts of teams foreign to California, ${ }^{316}$ STV dominates nearly half the Southern market (where broadcasters can still compete for games of the California Angels) and virtually the entire Northern market (where no rival teams exist).

This market position, however, does not constitute a violation of either the Sherman Act or Federal Trade Commission Act unless it poses an unreasonable restraint of trade. ${ }^{317}$ In FTC v. Motion Picture Advertising Serv. Co. ${ }^{318}$ the Supreme Court upheld the Commission's finding under section 5 of the FTC Act that exclusive contracts between theaters and the defendant were unduly restrictive of competition because they extended for periods in excess of one year. The Court noted that the precise impact of a particular practice on the trade turns on the exigencies of a particular situation, trade practices, and the practical requirements of the business in question. Many of the same economic factors which

Court in Brown Shoe Co. v. United States, 370 U.S. 294, 325-26 (1962). A number of factors were taken into account to determine a product submarket: 1) industry or public recognition of the submarket as a "separate economic entity," 2) the product's peculiar characteristics and uses, 3) unique production facilities, 4) distinct custoniers, 5) distinct prices, 6) sensitivity to price changes, and 7) specialized vendors. A brief survey of baseball demonstrates that it is a distinct sport recognized by the public and a sport requiring facilities unique to baseball and with a following of sport fans who, during the baseball season, have few alternative major sport attractions available to then.

315 In International Boxing Club of N.Y., Inc. v. United States, 358 U.S. 242, 249-51 (1959), the Court determined a relative submarket in the field of boxing in a manner which may be analogous to the problem of submarkets in baseball. The issue was whether the anticompetitive effects of owning Madison Square Garden and the promoter rights accompanying it should be weighed in a product market of all professional boxing or only championship boxing. The Court held that a separate, :identifiable narket for championship fights existed. Proof of the existence of such a market was found in "Nielsen" ratings which showed championship fights to be of greater viewer interest. Further, the broadcasting, motion picture and advertising industries were more interested in promoting the championship matches.

Nielsen ratings would probably reveal that California viewers had a greater interest in baseball games featuring California teams than games featuring out-of-state contestants. Similarly, an economic survey would probably show television broadcasters more eager to obtain rights to telecast games of California teams that to telecast games of out-of-state teams.

316 See, e.g., Prospectus, Subscription Television, Inc., Oct. 30, 1963, p. 12, where reference is made to a network production entitled "Game of the Week."

317 Ibid.

818344 U.S. 392 (1953). 
have been considered in Sherman Act cases have also been considered in cases of alleged violations of section 3 of the Clayton Act: The line of commerce is identified, the relevant market defined, and the probable effect on competition in that market weighed. ${ }^{310}$ In evaluating the effect on competition of exclusive arrangements, the Supreme Court has continually expanded the number of economic factors it considers. ${ }^{320}$ Particular attention has been paid to the purpose and duration of the agreement, the resulting barriers to the entry of newcomers into the market, the relative positions of the parties, and the ability of existing competitors to seek out other markets to replace lost business. ${ }^{821}$

The pay television industry can make the argument that exclusive long-term contracts are necessary for a steady supply of profitable and popular programs to attract large numbers of subscribers, without which the heavy capital investment required for installation cannot be obtained. Further, practical reasons may require that commercial television be barred from competition during the first one or two years. Subscribers will not pay for programs that are available on "free" television. The extended length of the STV contracts may nevertheless be objectionable since it prevents commercial stations from competing on a season to season basis. ${ }^{322}$ Commercial broadcasters do not have the opportunity to

318 Compare id. at 395 (a Sherman Act violation), with Standard Oil Co. of California v. United States, 337 U.S. 293 (1949) (a Clayton Act violation). It slould be noted that in FTC v. Motion Picture Advertising Serv. Co., 344 U.S. 392 (1953), more economic factors were weighed in making the determination than in Standard Oil (note also the dissent at 398 where even greater economic analysis was urged). One federal district court distinguished the use of economic data in these two cases on the ground that the latter was a Clayton Act $\S 3$ violation while the former was a Sherman Act \$§ 1 \& 2 violation. Anchor Serum Co. v. FTC, 217 F.2d 867, 872 (7th Cir. 1954). Yet in a later Supreme Court decision dealing with a Clayton Act $\S 3$ violation, the Court considered a greater number of economic factors than it had considered in Motion Picture Advertising. Tampa Elec. Co. v. Nasl1ville Coal Co., 365 U.S. 320, 330-35 (1961).

320 Tampa Elec. Co. v. Nashville Coal Co., supra note 319.

321 Ibid.

322 It would be misleading to suggest that any contract for more than one season is automatically open to attack, since in the televising of other sports the custom is to engage in contracts running up to five years. For example, NBC has obtained five year riglits to all American Football League games and two year rights to the football games of the National Collegiate Athletic Association. Broadcasting, April 6, 1964, p. 104. The television rights to the ganes of the National Football League liave also been a source of higlly competitive bidding. CBS won two year rights to tlese games. It appears from the position of the parties that these long term contracts were desired by the football leagues thenuselves. The NFL offered the networks a one year contract at a cost of $\$ 120,000$ per minute while two year contracts were offered at $\$ 110,000$ per minute. Broadcasting, May 11, 1964, p. 76.

To arrive at any definite conclusions on the permissible length of STV's basehall contracts, it would be necessary to survey the custom of the baseball sports broadcasting industry, the relative positions of the parties, and the economic conditions which miglit warrant an extended period. See, e.g., FTC v. Motion Picture Advertising Serv., 344 U.S. 392 (1953). 
find new substitute markets because the supply of local baseball teams is limited. The occasional network broadcasts of out-of-state teams will be open to exploitation but these games do not have the same viewer interest as do the games of California teams. Aside from the California Angels, the only supply of California baseball available to commercial broadcasters will be the Giant games played in San Francisco against outof-state teams and televised in Los Angeles, and the Dodger games played in Los Angeles against out-of-state teams but televised in San Francisco. ${ }^{323}$ The Dodger-Giant games played in either city will be excluded from this limited market. ${ }^{324}$ Yet these are the contests of greatest interest to the California viewers. The STV contracts liave the effect of skimming off the cream of the market with little left over for newcomers or existing commercial broadcasters. ${ }^{325}$ In short, while STV may demonstrate that exclusive contracts are necessary for the development of pay television, it is unlikely that the courts would be willing to permit exclusivity for the full fifteen-year period.

An alternative method of ensuring a steady supply of sports programming raises equally difficult antitrust questions. By integrating the ownership of pay television and sports organizations, program supply and permanent market foreclosure could be guaranteed. ${ }^{326}$ Althougl the percentage of STV stock owned by the Dodgers and Giants is not sufficient to warrant any claims of integration througln merger, ${ }^{327}$ it was widely reported that the Columbia Broadcasting System's purchase of the New York Yankees was prompted by the threat of merging baseball and pay television interests. ${ }^{328}$ If pay and commercial broadcasters scramble for ownership of sports teams, serious anticompetitive effects might

$\mathbf{3 2 3}$ The terms of STV's baseball contracts appear to permit this limited form of competition. Prospectus, Subscription Television, Inc., Oct. 30, 1963, pp. 11-16.

324 Ibid.

325 Cf. International Boxing Club of N.Y., Inc. v. United States, 358 U.S. 242, 251-52 (1959) (stock acquisition of sports arena permitted owners to capture the "cream" of the boxing exhibition market).

326 In United States v. Philadelphia Nat'I Bank, 374 U.S. 321, 366 (1963) the court stated that "integration by merger is more suspect than integration by contract because of the greater permanence of the former." Therefore, the generosity in weighing economic justifications which might be obtained in the area of exclusivity is less likely to occur in the field of merger; the Court in Philadelphia Nat'l Bank stepped away from the thorough market analysis of Tampa Elec. Co. v. Nashville Coal Co., 365 U.S. 320 (1961), and adopted the more easily administered test of Standard Oil Co. of California v. United States, 337 U.S. 293 (1949). See note 324 supra. Whether this trend will be confined to merger cases or applied more widely is not possible to predict.

327 On September 30, 1963 the Los Angeles Dodgers, Inc. and the National Exhibition Company (the San Francisco Giants) were expected to own $2.3 \%$ and $1.8 \%$ respectively of all STV Common Stock following general sale to the public. Prospectus, Subscription Television, Inc., Oct. 30, 1963, pp. 28-29.

328 See, e.g., Gould, New York Times, Aug. 17, 1964, p. 51, col. 2. 
result. A supplier's acquisition of a customer may substantially lessen competition by excluding competitors of the supplier from selling to the acquired customer. ${ }^{329}$ In measuring the effects of "vertical integration," a court must consider the same problems of "relevant market" discussed earlier. ${ }^{330}$ To decide whether a merger has substantially lessened competition or whether a monopoly lias been achieved, the court must decide the weiglit to be given the economic effect of a market foreclosure beyond a sliowing of a percentage market dominance. ${ }^{331}$

The pay television industry also appears to be moving toward lorizontal integration by combining with CATVs, film studios, and commercial broadcasting outlets. To the extent that the FCC has jurisdiction over pay television, its licensing policies may affect the development of vertical and horizontal integration. ${ }^{332}$ The FCC has already taken the position that ownership of commercial television should be diversified; ${ }^{383}$ however, there is no assurance that similar or other antimonopoly policies will be applied to pay television. As it las done in taking jurisdiction over all CATV ${ }^{334}$ the FCC will require further economic data before making a determination. ${ }^{335}$

\section{CONCLUSION}

Whatever the fate of California's ban on subscription television, the debate will go on. Subscription television promoters will decide to enter

329 See Brown Shoe Co. v. United States, 370 U.S. 294 (1962) (Clayton Act violation);

United States v. Colunbia Steel Co., 334 U.S. 495 (1948) (Sherman Act violation).

330 See notes 319-20 supra and accompanying text.

331 See note 319 supra and accompanying text.

- 332 For initial testing of pay television systems, the Commission has required applicants to demonstrate that their contracts are nonexclusive. The object is to prevent any individual station from acquiring a monopoly over a single system or combination of systems in any one test area. Subscription Television Serv., 23 F.C.C. 531, 549 (1957) (rule-making); Subscription Television Serv., 26 F.C.C. 265, 269 (1959) (rule-making); Hartford Phonevision Co., 30 F.C.C. 301,307 (1961) (decision on application).

333 Owners of CATV systems may not be granted licenses for commercial stations where those stations will be in competition with their own CATV. The FCC has reasoned that an identification of interests may eause the owner to favor the most lucrative investment, to the detriment of a public entitled to the benefits of a vigorous competition. See CATV and Repeater Servs., 26 F.C.C. 403, 440 (1959). In pursuit of diversification, the Conmission has passed over applicants who own newspapers in favor of those who do not have interests in conmunication media outside of broadcasting. See generally, Levin, Broadcast Regulation and Intermedium Competition, 45 VA. L. REv. 1104 (1959); Note, Newspaper-Radio Joint Ownership, 59 YaLE L.J. 1342 (1950).

334 See notes 59-65, 92-93 supra and accompanying text.

335 In any event, the existence of some FCC policy in this field further demonstrates the need for uniform treatunent of closed circuit and airwave pay tclevision. If the Commission takes a vigorous stand against all forms of combined ownership, promoters may be encouraged to select the wired system regardless of its technological and economic drawbacks. Only by placing both systems under a single regulatory authority, can the natural advantages of each system be fully appreciated. 
new markets; production companies will decide to whom they should offer new programs; commercial television interests will perhaps decide to enter the field of "pay TV"; theater owners will ponder their wisest course; filmmakers will reconsider their distribution outlet possibilities. The "pay TV" problem is more, in short, than a patchwork of federal, state and local regulatory problems, constitutional law problems, and antitrust policies. Millions of dollars and millions of viewers are concerned. In taking jurisdiction over CATV systems the FCC noted that if allowed to grow both unfettered by federal regulation and subject to the inconsistent commands of states and localities, CATV.presents a threat to the orderly development of the national broadcast policy souglit by the Communications Act.

This comment takes the view that the situation with respect to subscription television is no less insistent. FCC assertion of jurisdiction over all subscription television-by cable or airwave-is a necessary first step. Were the FCC to take jurisdiction, inconsistent state and local regulation would fall. As it did in the case of CATV, the FCC might leave to state regulation questions of cliarges for subscription television, and the use of imtrastate public utilities. Hopefully, however, the assertion of jurisdiction would, by dealing with program content, equal time, and fairness, ensure that subscription television promoters are subject to the same minimal requirement as those commercial television stations with whicl they are in competition.

It may well be, however, that because cable subscription television is not subject to the same limits on the number of available channels as is airwave broadcasting, the first amendment will interdict the FCC's assertion of jurisdiction over program content. At least, the Commission should be aware that the first amendment challenge to its jurisdiction in the $N B C$ case was turned aside on the "limited number of chaunels" argument, and so frame its assumption of jurisdiction as to make clear that it recognizes the limits of its power. Perhaps the standards for content control will have to be relaxed in the case of subscription television by cable. Perhaps, on the other hand, the practical himits on the number of subscription television outlets that can serve a given area, and the serious competitive advantage accruing to a broadcaster who need not follow the FCC's content guidelines, will justify application of undiluted content standards to cable subscription television broadcasters. The determmation must await evidence of the effect of pay television.

As to antitrust problems, the FCC could blunt many objections about control of program sources by applying consistent regulatory standards to commercial and subscription television alike. In a free-for-all struggle between regulated commercial television and unregulated subscription 
television, antitrust litigation seems an important, though costly and wasteful, weapon. Consistent regulation by the FCC would minimize the necessity for such hitigation.

Subscription television may harm commercial television. Viewer preference may dictate, in the fullness of time, that subscription television should supplant commercial television. The answer, this Comment has suggested, is not an a priori ban on one or the other of the contestants, but a regulatory scheme in the context of which viewers can make a rational choice. That regulatory scheme will have to face and deal with the problems of multiple regulation, constitutional law, and antitrust policy which it has been the purpose of this Comment to discuss.

\section{Theodore B. Olson* \\ Norman S. Oberstein*}

* LL.B. 1965, University of California, Berkeley; Member, California Law Review. The authors gratefully acknowledge the extensive editorial assistance of Charles A. Bell (LL.B., 1965, University of California, Berkeley; Note \& Comment Editor, California Law Review, 1964-65), without whose efforts this Comment would not have come to fruition. 